\title{
Land Use Effects on Climate: Current State, Recent Progress, and Emerging Topics
}

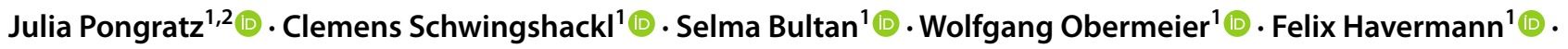 \\ Suqi Guo ${ }^{1}$
}

Accepted: 25 November 2021 / Published online: 27 December 2021

(c) The Author(s) 2021

\begin{abstract}
Purpose of Review As demand for food and fiber, but also for negative emissions, brings most of the Earth's land surface under management, we aim to consolidate the scientific progress of recent years on the climatic effects of global land use change, including land management, and related land cover changes (LULCC).

Recent Findings We review the methodological advances in both modeling and observations to capture biogeochemical and biogeophysical LULCC effects and summarize the knowledge on underlying mechanisms and on the strength of their effects. Recent studies have raised or resolved several important questions related to LULCC: How can we derive $\mathrm{CO}_{2}$ fluxes related to LULCC from satellites? Why are uncertainties in LULCC-related GHG fluxes so large? How can we explain that estimates of afforestation/reforestation potentials diverge by an order of magnitude? Can we reconcile the seemingly contradicting results of models and observations concerning the cooling effect of high-latitude deforestation?

Summary Major progress has been achieved in understanding the complementarity of modeling, observations, and inventories for estimating the impacts of various LULCC practices on carbon, energy, and water fluxes. Emerging fields are the operationalization of the recently achieved integration of approaches, such as a full greenhouse gas balance of LULCC, mapping of emissions from global models to country-reported emissions data, or model evaluation against local biogeophysical observations. Fundamental challenges remain, however, e.g., in separating anthropogenic from natural land use dynamics and accurately quantifying the first. Recent progress has laid the foundation for future research to integrate the local to global scales at which the various effects act, to create co-benefits between global mitigation, including land-based carbon dioxide removal, and changes in local climate for effective adaptation strategies.
\end{abstract}

Keywords Land use $\cdot$ Land management $\cdot$ Climate $\cdot$ Carbon cycle $\cdot$ Biogeochemical $\cdot$ Biogeophysical

\section{Introduction}

Human land use extends over three-quarters of the ice-free land surface [1]. Changes in land use may alter the Earth's land cover and may also encompass changes in the concrete type of management, which we summarize as land uses and

This article is part of the topical collection on Vegetation and Climate Change

Julia Pongratz

julia.pongratz@1mu.de

1 Ludwig-Maximilians-Universität München, Luisenstr. 37, 80333 Munich, Germany

2 Max Planck Institute for Meteorology, Bundesstr. 53, 20146 Hamburg, Germany related land cover changes (LULCC) in the following [2]. Examples of LULCC practices are displayed in Fig. 1. Quantifying LULCC effects on local to global climate is essential to understand the drivers of climate change and to assess the strength of the underlying human impact. Furthermore, climatic effects of LULCC can offer an effective way to reduce global warming (mitigation) or to adjust local climate such that impacts of climate change on living conditions are attenuated (adaptation). LULCC has received a new level of attention as most of the socioeconomic scenarios compatible with the Paris Agreement's goals require large-scale carbon dioxide removal (CDR), which includes afforestation or biomass plantations with carbon capture and storage (BECCS) $[3,4]$. Additionally, it has increasingly been recognized that non-greenhouse gas effects of LULCC-via exchange of 


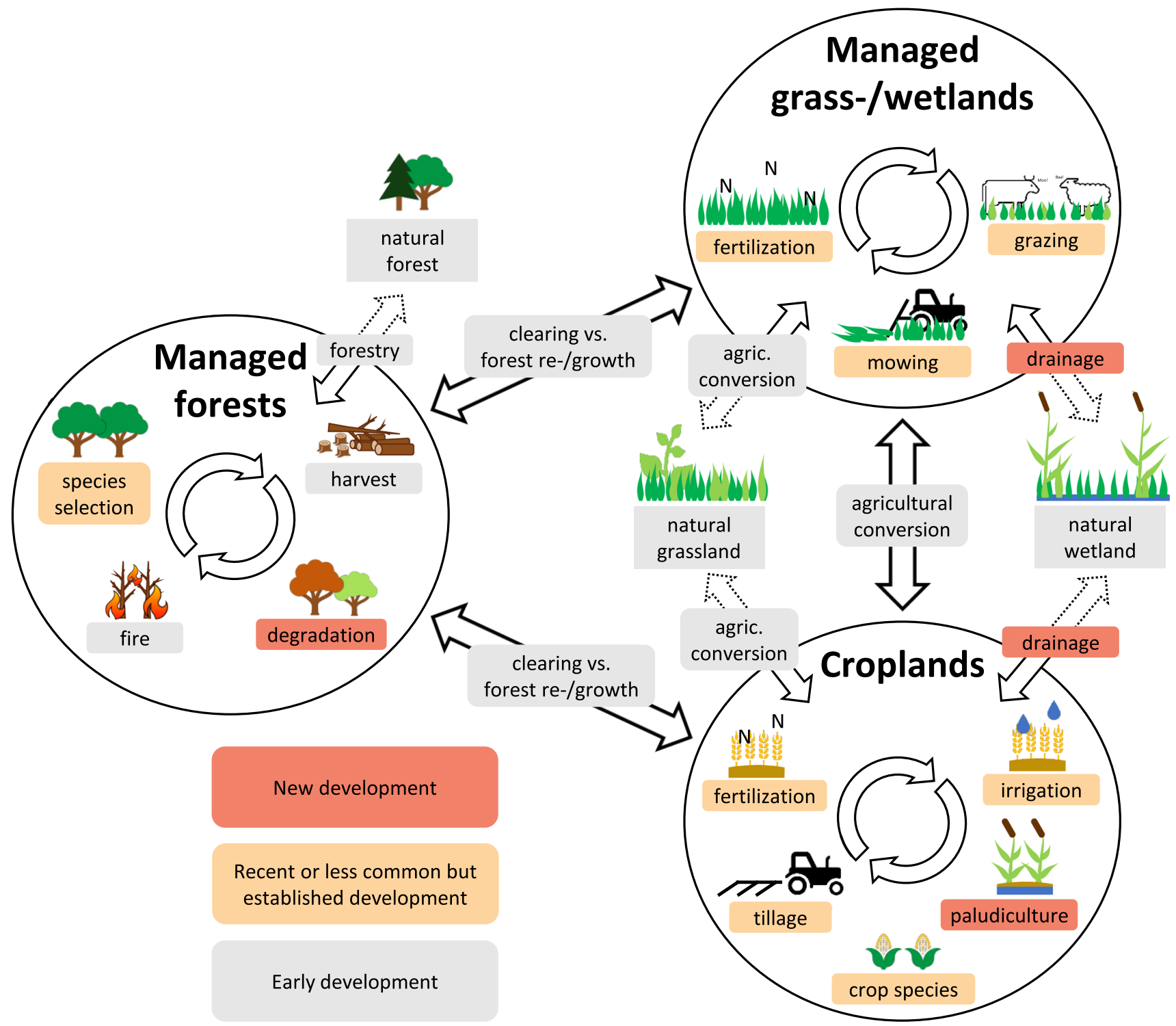

Fig. 1 The number of land use practices, including related land cover changes and land management (LULCC), that are represented in large-scale assessments (in particular in global modeling) has substantially increased over time. The stage of development is based on the assessment by Pongratz et al. [2], with "early" referring to prac-

water, energy, and momentum with the atmosphere-need to be considered as well for sound policy-making [5].

The pathways through which changes in vegetation cover impact climate have been well understood [6]. On the global scale, impacts of LULCC comprise predominantly greenhouse gas (GHG) fluxes and emissions of aerosol precursors (biogeochemical effects), mostly of $\mathrm{CO}_{2}, \mathrm{~N}_{2} \mathrm{O}$, and $\mathrm{CH}_{4}[4$, $7,8]$. Emissions of $\mathrm{CO}_{2}$ to the atmosphere are mainly due to the clearing of forests and other natural vegetation for conversion to agricultural land, degradation, wood harvesting and related product decay, peat drainage, and peat burning. Removals of $\mathrm{CO}_{2}$ from the atmosphere by LULCC are tices captured by the majority of "generation 1" (CMIP5) models and "recent" to other LULCC practices discussed or partly implemented as model features. "New" developments have emerged since. Dashed arrows indicate the potential reversion of managed land to its natural state

mainly due to reforestation and recovery of non-forest vegetation following agricultural abandonment, afforestation, and regrowth of forests following wood harvest $[4,9,10]$. The majority of $\mathrm{N}_{2} \mathrm{O}$ emissions stems from the application of nitrogen fertilizers, manure management, and biomass burning [11]. $\mathrm{CH}_{4}$ emissions are mainly caused by enteric livestock fermentation, biomass burning under incomplete combustion, and rice cultivation [12]. Furthermore, LULCC leads to changes in the physical properties of the land surface (in particular albedo, leaf area, and roughness; thus influencing evapotranspirative efficiency), altering the surface energy balance (biogeophysical effects). These changes 
are very specific for each type of conversion and each region $[13,14]$. They affect the climate both locally at the site of LULCC, e.g., through evaporative cooling, but, like GHGs, also in remote areas through advection of heat and moisture, and by altering atmospheric circulation ("non-local effects" [15]) (Fig. 2). The different scopes of these biogeophysical effects on local vs global climate create a challenge for political decision-making on LULCC.

Effects of global LULCC are routinely assessed by IPCC, e.g., in the IPCC Sixth Assessment Report (in particular Chapters 2 [16] and 5 [17]) and the IPCC Special Report on Climate Change and Land (Chapter 2 [4]). The recent years have seen major progress in a variety of fields not extensively addressed by these IPCC assessments: a larger range of methods to assess LULCC effects on climate; deeper insights into land-atmosphere processes, in particular across scales and with respect to synergies between LULCC and climate effects; and more comprehensive compilations of effects. In this review, we summarize this recent progress and discuss emerging fields of research. Therefore, the review covers only the latest research in the field, typically the last 5 years of publications. We split our review into methodological advances and advances in understanding and quantification of LULCC effects on climate. In each section, we complement a short review of the recent literature with spotlights on selected topical questions. We focus on scales that guide global climate policies, such as the global, multidecadal to centennial timescales of the Coupled Model Intercomparison Projects (CMIP) [18] and, thus, LULCC studies on sub-continental scales are not considered. Our scope is limited to climatic effects, but we emphasize that the full suite of ecosystem services (e.g., agricultural productivity, water and air quality, biodiversity, recreation [19-21]) needs to be considered to develop pathways in line with the United Nations' sustainable development goals.

\section{Methods to Assess LULCC Effects on Climate}

\section{Overview of Methods}

Biogeochemical and biogeophysical LULCC effects on climate are quantified through multiple methods including in situ measurements, inventory data, remote sensing observations, and different modeling approaches [10-12]. The different methods provide independent estimates and make complementary analyses possible (e.g., [22]), but the methodological differences in terms of the captured LULCC practices, GHG sub-component fluxes (e.g., emissions from deforestation, removals from forest regrowth), and spatial scales of biogeophysical effects need to be considered and estimates need to be harmonized prior to combining them for GHG flux estimates. The recognition of the massive methodological differences combined with proposals for how to resolve them has been a key achievement of the last few years, in particular in light of the fact that findings from fundamental sciences become increasingly relevant for real-world application as LULCC's political role in emissions reductions and CDR, but also awareness of side effects on water and energy fluxes, has increased (see Spotlight: How Can We Derive CO2 Fluxes Related to LULCC from Satellites? Spotlight: Why Are Uncertainties in LULCCRelated GHG Fluxes so Large? and Spotlight: Can We Reconcile the Seemingly Contradicting Results of Models

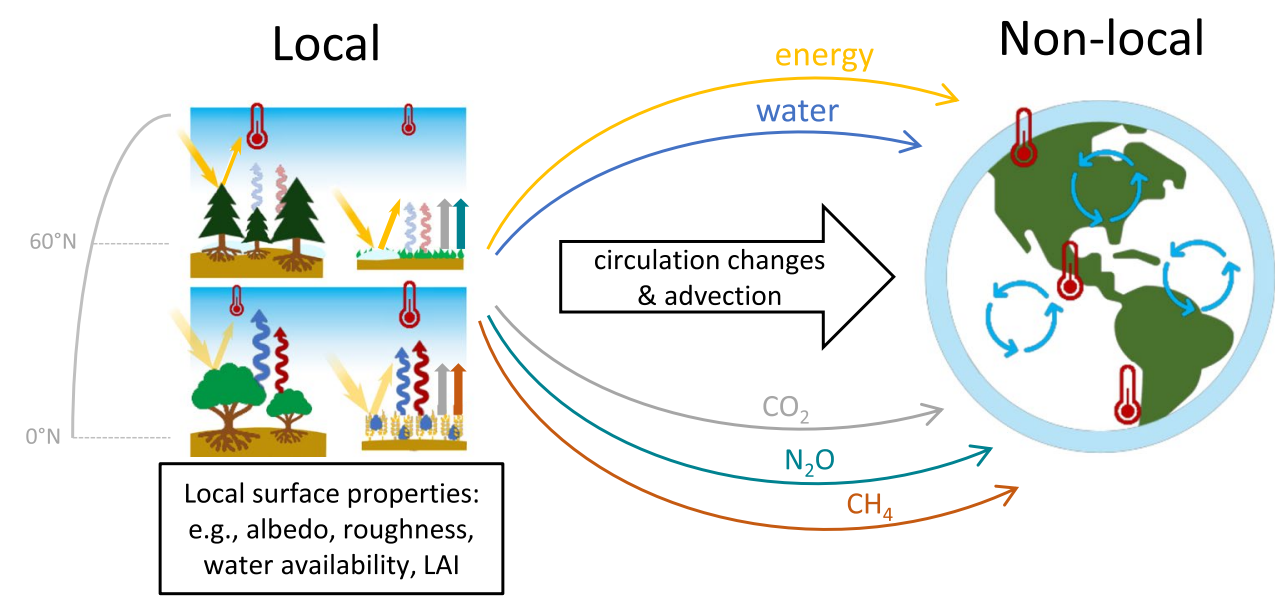

Fig. 2 LULCC alters local surface properties, which affect latent and sensible heat fluxes, the surface radiation balance, and greenhouse gas fluxes. Effects depend on vegetation types and location, in particular strong zonal differences exist. Thermometer symbols indicate lower land surface temperatures (small symbol) in non-forest land compared to forests in boreal regions (mainly due to roughness and albedo effects) and increased surface temperatures (big symbol) for cleared areas in the tropics (mainly due to evapotranspiration effects). Differentiating between local and total (local plus non-local) effects has helped reconciling local observational studies and coupled modeling studies. It is also crucial for identifying win-win situations between (local) adaptation and (global) mitigation 
and Observations Concerning the Cooling Effect of HighLatitude Deforestation?).

Models are a widely used tool for global-scale analyses of LULCC effects on climate, basing their assessments on differencing simulations with and without LULCC [23, 24]. Dynamic Global Vegetation Models (DGVMs), some of which also serve as a land surface component in fully coupled Earth System Models (ESM), are frequently used to estimate LULCC-induced removals and emissions of GHGs by vegetation and soils, often in model ensembles to attain more robust results (e.g., [10, 12, 25, 26]). Basic LULCC activities were already implemented in early-generation DGVMs and have been extended steadily [2]. The improvement of LULCC representation went in parallel with relevant improvements in general land surface process representation [27]. Recent progress includes processes such as grazing, irrigation, tillage, or plant species selection (see Fig. 1). Bookkeeping models are used to attribute anthropogenic GHG emissions and removals to different LULCC events (e.g., [11, 28-30]). Depending on the attribution approach, GHG fluxes can be tracked at the time of the event (instantaneous fluxes), as GHG fluxes that are triggered by the event but occur subsequent to the event (legacy fluxes) or as the sum of instantaneous and legacy fluxes but attributed to the time of the LULCC event (committed fluxes) (e.g., [31]). Furthermore, atmospheric inversion techniques allow us an indirect estimation of GHG emissions and removals, using atmospheric transport models and statistical methods to obtain those emission patterns that best fit observations (e.g., [32-34]). To translate estimates of GHG emissions from LULCC to climatic effects, if the climate is not simulated interactively within an ESM, the transient climate response to cumulative $\mathrm{CO}_{2}$ emissions (TCRE) can be applied, which on average is $1.77 \pm 0.37 \mathrm{~K} \mathrm{EgC}^{-1}$ based on 11 CMIP6 models [35].

DGVMs also simulate altered biogeophysical properties (e.g., surface albedo, roughness, leaf area) and processes (e.g., surface energy balance, latent, and sensible heat fluxes). To capture atmospheric feedbacks, they are usually coupled with the atmosphere, as in the Land-Use and Climate, IDentification of robust impacts (LUCID) project, which was the first structured model intercomparison project on biogeophysical effects [36]. To fully include climate feedbacks, additional coupling to the ocean is needed, as done in the transient ESM simulations of LUCID-CMIP5 for future LULCC scenarios [37-39]. To better understand model divergence (of biogeophysical but also biogeochemical effects) highly idealized ESM studies with clear LULCC protocols for large-scale deforestation were suggested as part of CMIP6 in the dedicated Land Use Model Intercomparison Project (LUMIP). LUMIP also covers simulations with alternative LULCC that identify mitigation potentials of LULCC effects under different future climate evolutions, comparison of coupled and land-only simulations to isolate feedbacks, and factorial simulations for a range of LULCC practices [24]. The separation of local and non-local effects of LULCC has been achieved through various approaches: some studies implicitly isolated the local effects in models by applying a neighboring areas comparison concept [40] or by comparing different vegetation types of the same grid cell in tile-level output [41]. Coupled models capture the total (local plus non-local) climate response to LULCC (Fig. 2) and, thus, methodological advances were developed to separate local and non-local effects: a "checkerboard" approach of altered and unaltered grid cells [15], comparing coupled vs offline simulations [42], or isolating far-reaching teleconnections in suites of regional simulations [43]. This split is essential since observations only cover local effects (see Understanding and Quantifying LULCC Effects on Climate). Surface energy balance decompositions (e.g., [44-46]) are applied to identify the driving mechanisms (heat and radiation fluxes) of the overall biogeophysical response, while factorial simulations (e.g., $[46,47])$ are performed to identify the effects of individual surface property changes (such as albedo or roughness).

Recent remote sensing-based approaches to derive GHG fluxes from LULCC on global scales (e.g., [48-50]) have focused on combining estimates of terrestrial carbon stocks with LULCC processes (see Spotlight: How Can We Derive $\mathrm{CO}_{2}$ Fluxes Related to LULCC from Satellites?) through imagery from airborne and terrestrial lidar, active and passive radar, and optical sensors in combination with groundbased measurements, theoretically or empirically derived allometric equations, root-to-shoot ratios, and machine learning approaches (e.g., [50-53]). Other estimates rely on statistical upscaling of in situ measurements [11, 54]. Data on GHG emissions and removals from LULCC are further provided by national GHG inventories from country reports to the United Nations Framework Convention on Climate Change (UNFCCC) [55] and by data collections on agricultural and forest GHG fluxes from the Food and Agriculture Organization of the United Nations [56-58]. Observational quantifications of biogeophysical LULCC effects are obtained either by a space-for-time approach based on satellite imagery (e.g., [14, 59]), from in situ observations such as Fluxnet sites (e.g., [13]), or directly from satellite time series capturing LULCC (e.g., [60]).

\section{Spotlight: How Can We Derive $\mathrm{CO}_{2}$ Fluxes Related to LULCC from Satellites?}

Recent approaches to employ satellite-based information to estimate $\mathrm{CO}_{2}$ fluxes from LULCC usually follow one of three approaches: (i) multiplying satellite-based information on area changes of different LULCC practices with either (partly satellite-based) estimates of soil and vegetation 
carbon densities or (ii) with emission and removal factors that prescribe the amount of carbon released or absorbed by terrestrial ecosystems upon a LULCC event; (iii) deriving $\mathrm{CO}_{2}$ fluxes directly from satellite-based time series of carbon stocks. Due to observational constraints, these approaches cover sub-component fluxes of the total LULCC flux only, often limiting themselves to aboveground carbon stock changes, excluding non-forest or non-woody vegetation, and/or focusing on forest losses, not covering regrowth. An example for (i) is Tyukavina et al. [61], combining forest cover loss observations with aboveground carbon densities. Though often applied to cumulated area changes over a longer timeframe, this method could be applied to time series of LULCC changes and would then be conceptually similar to the bookkeeping approach, with the important difference that the emission estimate is committed, i.e., legacy $\mathrm{CO}_{2}$ fluxes from potentially slow processes such as slash, soil carbon or product decay, or forest regrowth are not captured at the time they actually occur, but are attributed to the time of the LULCC event. This can considerably affect the estimation of $\mathrm{CO}_{2}$ fluxes over a given time period [29, 31]. An example for (ii) is Harris et al. [50], who employ both forest cover loss and gain observations. This method is equivalent to the IPCC gain-loss approach that quantifies net $\mathrm{CO}_{2}$ fluxes within a defined time frame as the difference between all removals and emissions of $\mathrm{CO}_{2}$ in terrestrial ecosystems. An example for (iii) is Baccini et al. [51] using a concept equivalent to the IPCC stock difference method. It requires less information than the gain-loss approach (e.g., time series for gain-loss approach vs cumulated carbon stock differences), but can only be used to estimate committed emissions, as $\mathrm{CO}_{2}$ fluxes are simply inferred by the difference in carbon stocks between two time steps [55].

Observations of carbon stocks as well as of vegetation cover changes rely on a range of assumptions. Global maps of area densities for carbon in woody biomass are often derived by combining inventory data and/or field measurements with ground-based systems, aerial and/or satellite imagery (e.g., [50, 51, 62]). A crucial part is the derivation of aboveground biomass from structural vegetation properties (e.g., diameter at breast height, tree height, wood density), which is done through empirically or theoretically derived allometric equations. Similarly, conversion factors are applied to convert dry matter to organic carbon, and belowground biomass carbon is inferred from aboveground biomass carbon through root-to-shoot ratios [63-65].

Satellite-derived differences in area estimates for forest loss mainly arise from different methodological assumptions. Deforestation is defined as forest loss accompanied by a change in land cover $[66,67]$ while the term "forest degradation"- - as defined in remote sensing approachesimplies biomass loss with no change in land cover since the tree canopy may recover in the years subsequent to the degradation event. Forest degradation may also alter the composition of the vegetation layers underneath the tree canopy, which is hardly detectable through satellite imagery. Vegetation biomass losses are thus not necessarily depicted in canopy cover dynamics and may vary strongly, depending, e.g., on the severity of the respective event [68]. The implications of methodological choices for area estimates of deforestation and forest degradation can be exemplified by comparing the widely used Global Forest Watch (GFW) dataset [69] with the PRODES dataset by the Brazilian National Institute for Space Research [70]. Recent estimates (2000-2018) of the deforested area in the Brazilian Amazon vary by 96\% [53] due to several reasons: While PRODES uses ancillary data from expert photointerpretation to detect (anthropogenic) clear-cut deforestation [71], GFW reports all disturbances (anthropogenic and natural) combined [69]. Additionally, the datasets capture different types of forests in terms of demography (PRODES: primary; GFW: primary and secondary) $[53,72]$. PRODES captures deforestation only, whereas GFW detects any type of forest disturbance resulting in a long- or short-term loss of tree cover (i.e., also includes forest degradation). Furthermore, GFW detects forest disturbances on a much smaller scale $(30 \mathrm{~m})$ than PRODES $(250 \mathrm{~m})$ [72]. The different spatial resolution is relevant not only for the captured processes but also for the approximation of gross carbon fluxes since the area estimates for forest losses within each grid cell are always net values resulting from the cumulated effect of both forest gains and forest losses within a grid cell [53]. At coarser spatial resolution, this may lead to spatial asymmetries between carbon removals and emissions, i.e., gross carbon fluxes do not cancel out to net zero [29, 51]. For forest degradation, the spatial resolution limits the distinction of different drivers, as logging, burning, and shifting cultivation may occur on areas $<1$ ha [68], i.e., even high-resolution datasets on forest degradation may miss selective removals due to logging [61], underestimating LULCC emissions [73].

Recently, the quantification of forest degradation and its drivers has become a stronger research focus, although most studies only cover the Brazilian Amazon and only some studies derive $\mathrm{CO}_{2}$ fluxes from forest degradation [51-53, $72,74,75]$. Multiple studies agree on an increased share of carbon losses and/or forest area losses due to forest degradation compared to deforestation in the Brazilian Amazon in recent years [51, 66, 67]. Matricardi et al. [67] even suggest that forest degradation rates may have surpassed deforestation rates by a factor of three in 2014. Qin et al. [53] find that $\sim 73 \%$ of the gross reduction in aboveground carbon in forests in the Brazilian Amazon between 2010 and 2019 can be attributed to degradation, which is similar to the pantropical estimate of $69 \%$ for 2003-2014 by Baccini et al. [51]. Moreover, several studies suggest that fires (anthropogenic and natural) have a higher potential for forest degradation in 
terms of aboveground carbon loss [74], areal extent [72], and severity of damage to the canopy [75] compared to logging. Longo et al. [74] suggest that up to $94 \%$ of aboveground carbon may be lost due to severe fire damage. Overall, this highlights the need for global-scale datasets depicting forest degradation in terms of area and $\mathrm{CO}_{2}$ fluxes.

Despite many advantages, there are some important limitations to all recent approaches to derive $\mathrm{CO}_{2}$ fluxes from satellite data beyond the mentioned limitation to subcomponent fluxes and, often, the restriction to quantifying committed emissions. Most importantly, satellite data lack the possibility to distinguish directly between anthropogenic and natural processes on a global scale, which is crucial for deforestation and forest degradation monitoring systems, such as REDD + (Reducing Emissions from Deforestation and Forest Degradation under UNFCCC) [56]. The fundamental problem is that LULCC processes co-occur with natural processes. Observed changes in forest cover may be due to LULCC, but could also be a consequence of natural disturbances. Deforestation trends and forest cover loss due to drought or insect damage, may they be climate change-related or not, often go in the same direction. Similarly, observed changes in carbon stocks reflect both LULCC effects and the response to environmental changes, such as rising temperature, increasing $\mathrm{CO}_{2}$ concentration, and nitrogen deposition. The inability of observational data to separate LULCC and natural processes on a global scale is one of the most important reasons for the widespread application of models, which are thus often used for estimating both LULCC fluxes and the natural terrestrial sink in the budgeting of anthropogenic effects on the carbon cycle [10]. An emerging research field is thus the integration of observational data into models to split anthropogenic and natural processes while capturing observed dynamics from both processes combined. Alternatively, ancillary data (such as using the information on the shape of disturbance to identify LULCC in PRODES) can be employed to split fluxes by disturbance types. Furthermore, the model output can be refined to provide the same type of information as the satellite-based estimates (e.g., committed emissions or aboveground biomass only), enabling comparison even of sub-component fluxes of LULCC on an apple-to-apple basis. Still, mapping of satellite-derived fluxes to model-driven estimates has to be done with care [76].

Satellite-based approaches for quantifying LULCC effects can further include major uncertainties from the choice of emission and removal factors that are applied to the specific LULCC event or the land cover type when calculating LULCC emissions by multiplying emission and removal factors with LULCC data [63]. Harris et al. [50] compared GHG fluxes estimated from IPCC Tier 3 local removal factors derived from U.S. forest inventory plots with IPCC Tier 1 global values and found that the latter result in a $38 \%$ stronger net global forest carbon sink. Cook-Patton et al. [77] suggest that IPCC factors for carbon removal underestimate the assimilation of aboveground carbon in forests by onethird. Furthermore, the majority of observational datasets only provide vegetation carbon estimates for forests and sometimes woody vegetation, although a strong contribution of soil organic carbon to the interannual variability of the global terrestrial carbon cycle has been found [78]. Similarly, there is a lack of global remote sensing-based time series on forest regrowth [50], which hinders assessments of $\mathrm{CO}_{2}$ removals and, ultimately, the application of the gain-loss approach from remote sensing datasets.

\section{Spotlight: Why Are Uncertainties in LULCC-Related GHG Fluxes so Large?}

Accurate estimates of $\mathrm{CO}_{2}$ fluxes are essential for assessing changes in the global anthropogenic carbon cycle as provided, for instance, by the annually updated global carbon budget (GCB) of the Global Carbon Project [10]. The highest relative uncertainties within the most recent estimates are related to carbon fluxes from LULCC [10, 79]. These originate from uncertainties in (1) the underlying LULCC maps, (2) different comprehensiveness and levels of complexity of the LULCC practices implemented in models, (3) lack of observational constraints for model parameters and methodologies for the processing of satellite data, (4) different model assumptions and setups, and (5) inconsistencies in common terminology and definitions.

(1) Historical land use is not known perfectly and remains intrinsically uncertain for the future due to scenariodependent assumptions of upcoming land use pathways [80-82]. Reconstructions differ depending on the estimated patterns, transitions, and considered categories of land use as well as the spatial resolution [82-84]. Historical data is frequently revised and can have substantial impacts on carbon fluxes. A recent revision of the underlying land use areas reported by countries to the Food and Agricultural Organization's FAOSTAT [85] combined with a change in how national estimates of agricultural areas are distributed in space is the main reason for a change in trend from increasing to decreasing LULCC emissions in recent years (from GCB2020 to the data release of GCB2021). Yet, the uncertainties are very large, and the change in trend is thus not statistically significant [79]. For satellite-based LULCC data, further uncertainties arise due to the difficulty of distinguishing anthropogenic from natural and climate-driven LULCC dynamics on a global scale (see Spotlight: How Can We Derive $\mathrm{CO}_{2}$ Fluxes Related to LULCC from Satellites?). For reconstructing land use, country-reported data on agricultural areas and 
forest harvest, often from FAOSTAT [85] and the Forest Resource Assessments [86], is typically included to isolate the anthropogenic signal [82]. Integrating better satellite-based and country-reported data on a global scale is clearly a promising path towards reducing the uncertainties around land use dynamics, but also the translation of country-reported data to land use dynamics as input to models could be substantially improved: Rosan et al. [87] point out that retrospective updates in data reported by Brazil to FAO caused discrepancies between agricultural expansion and forest cover changes, which were attributed to the FAO "other land" category and thus remained unused by current global datasets [88], although they may contain part of a land use-induced deforestation signal. Additional uncertainties arise from the translation of land use data into land cover conversion [89]. As land use maps are used in DGVMs, bookkeeping models, and satellite-based stock change approaches, the associated uncertainties in land use patterns are propagated to the majority of GHG flux estimations (Table $1[28,90]$ ).

(2) The degree of implementation of LULCC practices (e.g., degradation, drainage, grazing, irrigation, shifting cultivation, wood harvest) varies across models as highlighted in Fig. 1 and Table 1 [10, 90-93], and practices can be implemented with very different complexity and process realism [2, 94].

(3) LULCC $\mathrm{CO}_{2}$ flux estimates are very sensitive to model parameterizations that are often not well constrained by observational data and differ between models, such as carbon densities in bookkeeping models and allocation of wood to slash and product pools of different lifetimes (Table 1, e.g., [95, 96]). At least regionally, emergent constraints are promising, for instance between initial biomass and LULCC emissions [97], as are efforts to constrain relevant soil and vegetation variables for a better representation of the processes underlying LULCC emissions [98, 99]. Satellite-based estimates of $\mathrm{CO}_{2}$ fluxes from LULCC face uncertainties arising from spatial upscaling of locally or regionally derived allometric equations, conversion factors, and root-to-shoot ratios to the global scale. Uncertainties from field plot sampling and allometric equations alone can account for up to $50 \%$ of the total aboveground biomass estimate [100], with further uncertainties contributed by the spatial transferability of the derived functions [65]. Estimations of areas affected by deforestation or forest degradation vary strongly across datasets (see Spotlight: How Can We Derive CO2 Fluxes Related to LULCC from Satellites?), contributing additional uncertainty.

(4) The most common DGVM approach to derive $\mathrm{CO}_{2}$ fluxes from LULCC (using transient environmental forcing) yields widely increased $\mathrm{CO}_{2}$ flux estimates as it includes the loss of additional sink capacity (LASC [23]). The LASC originates from carbon stocks of potentially existing but changed vegetation that would have profited from subsequent environmental changes (e.g., in cleared forests due to increasing atmospheric $\mathrm{CO}_{2}$ ). It makes up about $40 \%$ of the LULCC $\mathrm{CO}_{2}$ emission estimates from transient DGVM simulations during 2009-2018 (Table 1 [25]). The LASC strongly depends on the timing of a LULCC event and on the subsequent environmental changes which are often heterogeneous over time and across space [25]. To resolve this issue, time-independent DGVM estimates of anthropogenic $\mathrm{CO}_{2}$ emissions under fixed preindustrial or present-day environmental forcing can be used. However, in these approaches, carbon stocks do not adapt to environmental changes over time, which causes presumably strong underestimations and/or overestimations of the $\mathrm{CO}_{2}$ fluxes from LULCC for later or earlier periods, respectively. Similar to the present-day DGVM forcing, bookkeeping models use time-invariant response functions derived from observed carbon densities to calculate $\mathrm{CO}_{2}$ fluxes from LULCC, yielding presumably biased estimates under differing past and future environmental conditions.

(5) National GHG inventories based on country reports to UNFCCC or data submitted by countries to FAO [101] are frequently compared to the estimates of net LULCC emissions by DGVMs and bookkeeping models (e.g., [22]), yet they differ fundamentally in their scope. While global carbon cycle models distinguish anthropogenic from natural fluxes based on processes and drivers, country-reported data distinguish fluxes based on area, through the adoption of the IPCC managed land proxy approach, which assumes that all carbon fluxes on land declared as managed are anthropogenic. As a consequence, fluxes due to environmental changes are always treated as natural in models while national GHG inventories attribute part of the fluxes caused by environmental changes to the land use sector when they occur on managed land. This terminology difference explains about $80 \%$ of the difference between global carbon cycle models and national GHG inventories (Table 1, Grassi et al. [102]). Adjustments have been developed that allow for a translation and, thus, direct comparison of modeled and inventory-based GHG fluxes [102, 103]. An application to the annual updates of the global carbon budget shows the global carbon cycle models are consistent with the national GHG inventories when parts of the natural sink on managed forests-making up almost half of the total natural land sink-is redistributed to the land use sector [79]. When considering natural fluxes on managed land, the net 


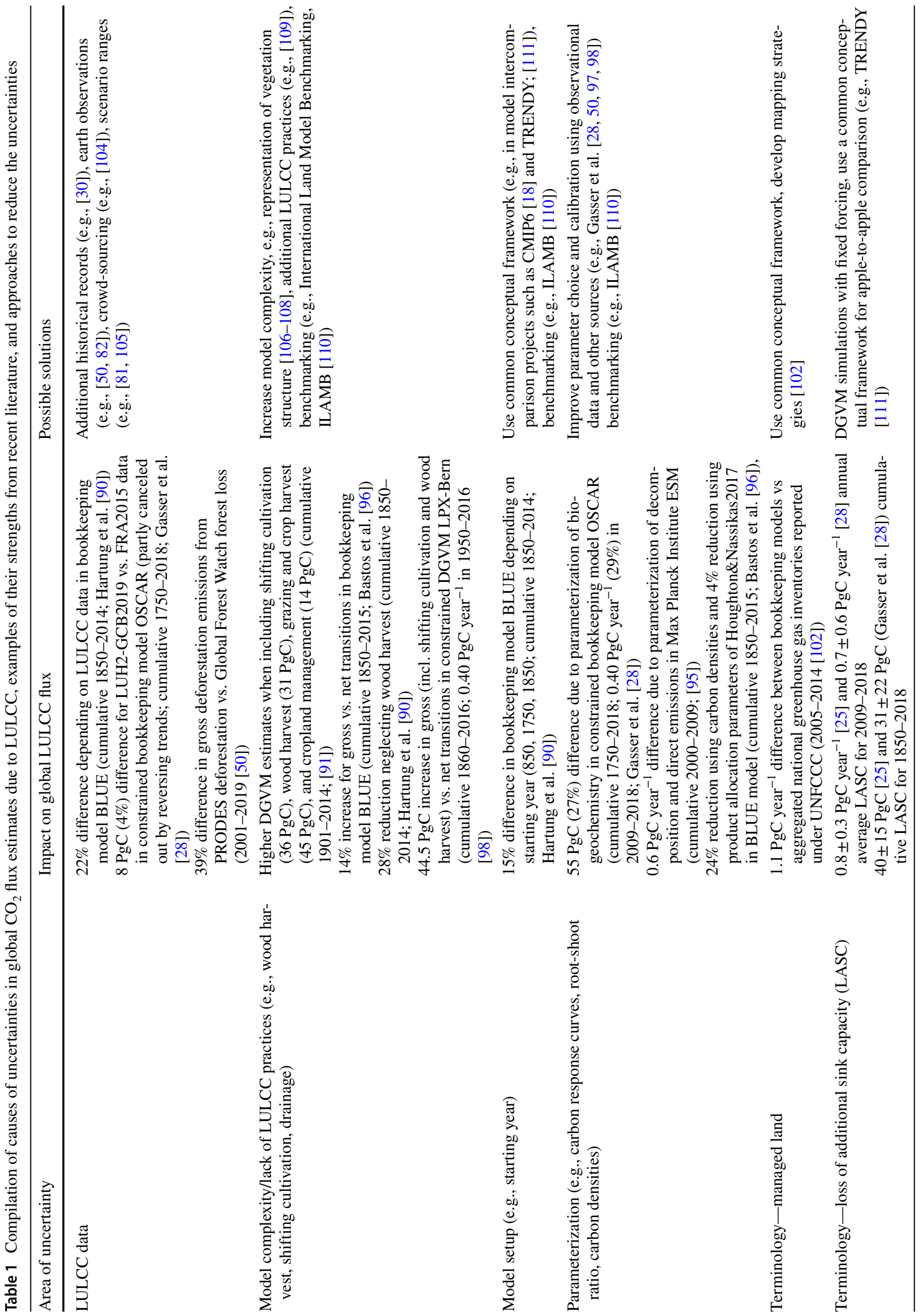


land use flux globally turns from a substantial source of $\mathrm{CO}_{2}$ emissions in the global models' assessment (see Biogeochemical Effects) to a $\mathrm{CO}_{2}$ sink reported by countries [79]. This reallocation of carbon fluxes reduces the allowable emissions for reaching a climate target by currently around $1.5 \mathrm{PgC}_{\text {year }}{ }^{-1}$ compared to the estimates from global socioeconomic models [102]. Connecting the annual updates of land use emissions from models to national GHG inventories opens the path to an operational assessment of the collective countries' progress towards mitigation in the land use sector as it avoids double accounting for parts of the natural terrestrial sink. Also, the successful translation between the two approaches could provide the opportunity to fill gaps in the national GHG inventories, which, in particular for non-Annex-I countries, are not annual and do not cover the most recent years.

We conclude from our review of recent methodological advances that modeling and observations of LULCC effects have each substantially improved. They can be linked in a more comprehensive way now that their differences and complementarities have been identified; most notably, the split into local and non-local effects, a mapping of country-reported data of GHG emissions to global model estimates, and the robust quantification of the loss of additional sink capacity have been achieved. Further methodological advances are needed to integrate satellite observations with models with respect to separating natural from anthropogenic drivers and including underrepresented processes such as degradation in models. Fundamental progress is also needed on accurate quantifications of land use dynamics.

\section{Understanding and Quantifying LULCC Effects on Climate}

\section{Biogeochemical Effects}

Despite growth in population and production per person, total LULCC emissions $\left(\mathrm{CO}_{2}, \mathrm{CH}_{4}, \mathrm{~N}_{2} \mathrm{O}\right)$ remained relatively constant at $\sim 11 \mathrm{PgCO}_{2} \mathrm{e}\left(\mathrm{CO}_{2}\right.$-equivalent using 100 year Global Warming Potential) throughout the second half of the last century, mainly due to the higher production efficiency of land area. However, the last two decades may have seen a surge in emissions per land area and across the globe due to cropland clearing in carbon-dense tropical forests [8]. LULCC is thus responsible for $25 \%$ of anthropogenic (LULCC + fossil) emissions [8]. Net $\mathrm{CO}_{2}$ emissions related to LULCC conversions and forestry represent about half (39-61\%) of all LULCC-related GHG emissions 1961-2017-or about 10-15\% of total (land use plus fossil) 
anthropogenic $\mathrm{CO}_{2}$ emissions for the last decade [10, 79]while $\mathrm{CH}_{4}$ and $\mathrm{N}_{2} \mathrm{O}$ emissions from agricultural management make up the rest [8]. Emissions from tropical regions remain high due to extensive growth of agricultural production (in particular cereals and oil crops) into often pristine, carbon-dense forests. Summing up all GHGs, Latin America, Southeast Asia, and sub-Saharan Africa cause about half of the net cumulative emissions in 1961-2017 [8].

Over the past half-century, LULCC caused relatively stable $\mathrm{CO}_{2}$ emissions of about $1.4 \pm 0.7 \mathrm{PgC}_{\text {year }}{ }^{-1}[10]$. While the growth in fossil emissions has decelerated since the Paris Agreement, within the (large) uncertainties there is no evidence that LULCC emissions show a significant decline $[10,79,112]$. Furthermore, there are indications that emissions may be underestimated as the land use change data does not capture fully recent deforestation increases in Brazil; interannual variability in the agricultural areas underlying the land use change data may be underestimated, which, due to the asymmetry between fast decay and slow regrowth, would underestimate net emissions; degradation, which seems to rise in importance in terms of area and carbon losses recently (see Spotlight: How Can We Derive $\mathrm{CO}_{2}$ Fluxes Related to LULCC from Satellites?), is not fully captured by the bookkeeping models [79]. For the very recent years, effects of the pandemic on global land use emissions have yet to be determined-regional evidence suggests that monitoring capacities and legal enforcement of measures to reduce tropical deforestation have been reduced and environmental protection policies may have been weakened in certain countries [79].

Further expansion and intensification of agriculture, anticipated in potential future scenarios [81], may again increase LULCC emissions. At the same time, however, land-based negative emissions are needed at a large scale [3], as creating gross $\mathrm{CO}_{2}$ sinks on land to meet the Paris Agreement's goals becomes more urgent each year. Distinguishing gross sinks/removals from gross sources/emissions is thus a priority for LULCC flux estimates (note that gross removals and emissions refer to $\mathrm{CO}_{2}$ fluxes, not to whether the underlying LULCC transitions are net or, including subgrid-scale back-and-forth transitions, gross; net vs gross transitions are assessed in Table 1). Currently, gross emissions are 2-4 times larger than the net LULCC emission term, showing the relevance of land management such as harvesting or rotational agriculture [10,79]. Gross emissions remained high over the last decades, reaching $3.8 \pm 0.6 \mathrm{PgC}$ year $^{-1}$ 2011-2020 [79]. Over the historical period, Erb et al. [113] estimated that land management (especially management of tropical forests and grazing on natural grasslands) contributed $42-47 \%$ and land cover change (to artificial grassland and cropland) $53-58 \%$ to the total reduction in global terrestrial carbon stocks, from potentially $916 \mathrm{PgC}$ to actually $450 \mathrm{PgC}$. LULCC contributes to the interannual variability (IAV) of terrestrial carbon stocks, with a standard deviation over recent decades of about $0.25 \mathrm{PgC}_{\text {year }}{ }^{-1}$ due to LULCC variability and the climate sensitivity of decaying slash material [114] (higher, when IAV of the natural terrestrial sink on managed land were counted towards LULCC fluxes [115]). Using CMIP6 and LUMIP experiments, Ito et al. [116] found only modest land use effects on soil organic carbon at the global scale, comparable to climatic and rising $\mathrm{CO}_{2}$ impacts, but pronounced effects in several regions, albeit models differ in sign of the effects. In particular, the transition to cropland, foremost to industrialscale cropping, was found to be the LULCC conversion leading to most soil carbon loss $[117,118]$. The GCB estimates include emissions from peat burning and drainage of organic soils, which have been estimated for 1960-2019 to globally 2.0 PgC [119] and 8.6 PgC (FAOSTAT [120]). Respecively, of the total $85 \pm 45$ PgC LULCC emissions. Note that drained organic soil emissions have been below $0.2 \mathrm{PgC}$ year $^{-1}$ in these estimates over the last decades, while other estimates [121] put them at $0.35 \mathrm{PgC}$ in 2008 (with the largest emitter Indonesia, followed by the EU) or, for cultivated northern peatlands alone, at $0.15 \mathrm{PgC} \mathrm{year}^{-1} 1990-2000$ [122], related to divergent estimates of drainage extent and emission factors. These higher estimates may challenge the scientific closure of the anthropogenic carbon budget [122], but would imply an underestimated mitigation potential for rewetting of agricultural areas [121] that have a massively overproportional $\mathrm{CO}_{2}$ footprint per calorie [7].

The abovementioned estimates of the annual global carbon budgets are derived as the mean value of three bookkeeping models and the (pronounced) uncertainty depicts the standard deviation of an ensemble of 17 DGVMs [10]. The LULCC-related emission estimate from DGVMs is significantly larger than the bookkeeping estimate, mainly because the transient DGVM approach includes the LASC (responsible for $\sim 40 \%$ of today's global emission estimate under transient environmental conditions; see Spotlight: How Can We Derive $\mathrm{CO}_{2}$ Fluxes Related to LULCC from Satellites? and [25, 123]). However, DGVMs yield strongly differing estimates depending on the process that are included: simulations that consider land use processes such as shifting cultivation, wood harvest, grazing and crop harvest, and cropland management show increased historic LULCC emissions by 20-30\% for each of these processes (Table 1 [91]). In contrast, aggregated national GHG inventories (under the UNFCCC) estimate much lower (or even negative) emissions from LULCC mainly because fluxes due to environmentally induced carbon stock changes on managed land (e.g., forest) are counted towards the land use sector (while the global models' definition attributes these fluxes to the natural carbon sink; see Spotlight: Why Are Uncertainties in LULCC-Related GHG Fluxes so Large? and [22, 79, 102]. In line, Tubiello et al. [57], using a carbon 
stock change approach for the period 2011-2020, found net removals on forest land (globally $0.9 \mathrm{PgC} \mathrm{year}^{-1}$ ) that counterbalanced the emissions from forest conversion $(0.85 \mathrm{PgC}$ year $^{-1}$ ).

The human production of reactive nitrogen has vastly accelerated over the last decades to dominate natural processes, with severe environmental impacts [124]. Global human-induced $\mathrm{N}_{2} \mathrm{O}$ emissions increased by $30 \%$ over the past four decades to $7.3 \mathrm{Tg} \mathrm{N}$ year $^{-1}$ (minimum-maximum estimates: 4.2-11.4) for the period from 2007-2016 (particularly strong in the emerging economies Brazil, China, and India and accelerating from 2009 onward [11, 32]). The by far highest share of $\mathrm{N}_{2} \mathrm{O}$ emissions is related to LULCC, and the relative contribution to non- $\mathrm{CO}_{2} \mathrm{GHG}$ emissions from agriculture has increased since the 1960s [125]. Reviewing various bottom-up and top-down studies, Scheer et al. [126] found that agricultural activities contributed to $5.0-6.8 \mathrm{Tg}$ $\mathrm{N}$ year ${ }^{-1}$ to the current terrestrial $\mathrm{N}_{2} \mathrm{O}$ budget, which is the majority of global human-induced $\mathrm{N}_{2} \mathrm{O}$ emissions. Similarly, but excluding indirect emissions downwind/downstream, Tian et al. [11] estimate annual average emissions for 2007-2016 from $\mathrm{N}$ additions in the agricultural sector $(\mathrm{N}$ fertilizer and animal manure) of 3.8 (2.5-5.8) $\mathrm{Tg} \mathrm{N}_{\mathrm{Near}}{ }^{-1}$. Thereof, 2.3 (1.4-3.8) $\mathrm{Tg} \mathrm{N}_{\text {year }}{ }^{-1}$ was direct soil emissions while the rest was predominantly manure left on pasture and with minor contributions from manure management and aquaculture. Climate change (particularly warming) further fastened this increase in soil $\mathrm{N}_{2} \mathrm{O}$ emissions by boosted nitrification and denitrification processes (terrestrial denitrification doubled to $160 \mathrm{Tg} \mathrm{N}$ year $^{-1}$ between the pre-industrial state and 2005 [11, 126, 127]. Tian et al. [11,32, 127] call this the $\mathrm{N}_{2} \mathrm{O}$-climate feedback and, by using process-based models, found a considerably larger global agricultural soil emission factor of $1.8 \%(1.3-2.3 \%)$ than assumed in IPCC tier 1 (1\%). Similarly, Thompson et al. [32] using three global atmospheric inversion frameworks found a global emissions factor of $2.3 \pm 0.6 \%$ for combined direct and indirect emissions, which is significantly larger than the IPCC tier 1 default of $1.375 \%$. Additional $\mathrm{N}_{2} \mathrm{O}$ fluxes related to LULCC are $0.8(0.7-0.8) \mathrm{Tg} \mathrm{N}$ year $^{-1}$ emissions from the, post-deforestation pulse effect (temporary increase in $\mathrm{N}_{2} \mathrm{O}$ emissions after deforestation) and $1.1(1.0-1.1) \mathrm{Tg} \mathrm{N}$ year ${ }^{-1}$ reduced emissions from the long-term effect of reduced mature forest area (tropical mature forests emit comparably much $\mathrm{N}_{2} \mathrm{O}$, [11]).

Saunois et al. [12] provide the most recent and comprehensive estimates of global $\mathrm{CH}_{4}$ emissions from agriculture and waste, based on bottom-up estimates (processoriented models, inventory models, satellite-based models, observation-based upscaling models) and constrained by atmospheric inversions (top-down approach). For the last decades, Saunois et al. [12] found increasing $\mathrm{CH}_{4}$ emissions from agriculture and waste, excluding fluxes from managed wetlands (partly included under UNFCCC), inland water and thawing permafrost, to annually averaged 206 (191-223) $\mathrm{Tg}$ $\mathrm{CH}_{4}$ in 2008-2017, which comprises $~ 56 \%$ of total anthropogenic $\mathrm{CH}_{4}$ emissions. Thereof, the by far largest source was livestock, particularly cattle in intensive agricultural systems of wealthier and emerging economies [125], with estimated emissions from enteric fermentation and manure management (the latter causing $\mathrm{CH}_{4}$ fluxes mainly under anaerobic conditions) of 111 (106-116) $\mathrm{Tg} \mathrm{CH}_{4}$ year $^{-1}$ [12], which is in agreement with the recent IPCC Tier 2 estimate of $99 \pm 12 \mathrm{Tg} \mathrm{CH}_{4}$ year $^{-1}$ for 2012 [128]. Rice cultivation contributes 30 (25-38) $\mathrm{Tg} \mathrm{CH}_{4}$ year $^{-1}$ globally, mainly due to periodic flooding and aeration of paddy rice fields and fertilization [12]. Asia contributes $30-50 \%$ to global $\mathrm{CH}_{4}$ emissions from rice cultivation [129], but over recent decades most inventories show a decreasing trend due to reduced areal extent, changed management, and northward shift of rice cultivation [12]. Field burning of agricultural residues is reported as a minor source of $\mathrm{CH}_{4}$ in emission inventories.

\section{Spotlight: How Can We Explain That Estimates of CDR Potentials by Afforestation/Reforestation (A/R) Diverge by an Order of Magnitude?}

Recent reviews of $\mathrm{A} / \mathrm{R}$ show CDR potentials of $0.1-2 \mathrm{PgC}$ year $^{-1}$ (in 2050) [3] or even higher [20, 130]. This very large range may not be misinterpreted as uncertainty in process understanding since it is partly attributable to different scopes of the individual studies underlying these reviews. Their scopes differed with respect to the type of potential considered, i.e., whether biophysical, technical, or economic limitations are considered [3], and with respect to the underlying scenario assumptions of background climate and available land [17]. However, several other sources of uncertainty have received little attention so far:

While competition with food has generally been recognized as a major constraint to $\mathrm{A} / \mathrm{R}$ areas [131], assumptions vary for presumably subtle, but highly important aspects such as if only current cropland (about one-third of total agricultural area) are spared from A/R [20, 132] or also grazing land and areas of future cropland expansion, which would additionally reduce CDR potentials by $20-60 \%$ [133].

Similarly, little attention is given to the most fundamental question of what a forest is. Thus, in many studies, fixed biome-wide sequestration potentials are used [20, 132], such that the $\mathrm{A} / \mathrm{R}$ area translates linearly to CDR. However, the area eligible for $\mathrm{A} / \mathrm{R}$ is reduced by two-thirds, or 5 million $\mathrm{km}^{2}$, when a crown cover threshold of $10 \%$ instead of $30 \%$ is assumed [134]. Griscom et al. [20], for example, assume a crown cover threshold of $25 \%$ for forests; the FAO uses the definition of $10 \%$ [86].

While static emission factors are a common approach to assess GHG fluxes from LULCC [135], fixed sequestration 
potentials ignore that regrowth of biomass and soil carbon is slow and non-linear [136] and that carbon uptake per unit area of $\mathrm{A} / \mathrm{R}$ may be much higher in the future than today due to beneficial $\mathrm{CO}_{2}$ effects on plant growth [137], or lower, as disturbances increase $[138,139]$ and, under strong mitigation, ecosystems start to outgas $\mathrm{CO}_{2}[140,141]$.

A common misperception is a fact that the sequestration potential on a given $\mathrm{A} / \mathrm{R}$ area (without product usage) would inevitably saturate [131], while studies show that even old-growth forests continue to be a carbon sink currently (between $1.6 \pm 0.6 \mathrm{Mg} \mathrm{C}^{-1}$ year $^{-1}$ and $2.4 \pm 0.8 \mathrm{Mg} \mathrm{C}$ $\mathrm{ha}^{-1}$ year $\left.^{-1}\right)[142,143]$ in many regions in response to more favorable growth conditions (the same processes that are underlying the loss of additional sink capacity). Nonetheless, the magnitude of CDR potential and its persistence in the future under elevated $\mathrm{CO}_{2}$ concentrations still needs to be analyzed in detail [144].

Lastly, the future divergence between estimates will partly stem from biogeophysical effects of $\mathrm{A} / \mathrm{R}$ being considered in studies quantifying CDR potentials of $\mathrm{A} / \mathrm{R}$ : if at all, in the past, only albedo aspects were accounted for [20, 145]; this was recently extended to account for all biogeophysical effects [146] on a local scale, but far-reaching climatic effects have to date not been considered (see Biogeophysical Effects and Spotlight: Can We Reconcile the Seemingly Contradicting Results of Models and Observations Concerning the Cooling Effect of High-Latitude Deforestation?).

We conclude from our review of biogeochemical effects that a full GHG coverage has been achieved for LULCC, though not yet operationally each year, and can serve as independent data to evaluate assessments under the Global Stocktake. Though LULCC emissions are of secondary importance to fossil emissions currently, at around a quarter of total emissions they are large and remained high despite continuing international climate negotiations. Estimates of future LULCC effects need to consider that LULCC comprises many readily available CDR methods. The last years saw major progress in providing reviews of CDR potentials for a range of methods [3, 4, 20, 147]. To narrow down the large ranges, harmonization of fundamental differences (such as forest cover definition) needs to be achieved.

\section{Biogeophysical Effects}

The strength of biogeophysical LULCC effects on regional and global climate is still a matter of debate. Despite the identification of a large spread among models in LUCID [148] and the following substantial progress in the representation of terrestrial processes and LULCC practices in models [2, 27], more recent model intercomparison studies still find that not all models agree on the sign of global and regional temperature changes for historical [149, 150], future [37], and idealized [151] LULCC scenarios. Some major differences between model studies with different setups and between models and observations, however, could be attributed to different scopes of the studies (see Spotlight: Can We Reconcile the Seemingly Contradicting Results of Models and Observations Concerning the Cooling Effect of High-Latitude Deforestation?). We report in the following robust conclusions of the last years and major ongoing research areas.

A better understanding of the effects of deforestation and $\mathrm{A} / \mathrm{R}$ has emerged as the very distinct signals of local vs nonlocal effects (Fig. 2), the latter sometimes termed "atmospheric feedbacks" [42], have been recognized and methodological advances allowed for their separation [15, 42]. A largely consistent picture of local effects across models and observations is an annual mean near-surface air warming effect of deforestation (or cooling for $\mathrm{A} / \mathrm{R}$ ) in almost all of the tropical and mid-latitudes, which can reach more than $1{ }^{\circ} \mathrm{C}$, and a cooling effect in some or all of the boreal region $[13,14,60,149]$. Deforestation amplifies the diurnal cycle of local surface temperature across the globe $[14,60$, $150]$ and increases the intensity of hot days in many regions [152], although models still struggle reproducing observed diurnal changes well [38]. The tropical and temperate warming is attributable to the decreases in turbulent heat fluxes due to decreased roughness and transpiring leaf area $[13,14$, 46]. In boreal regions, summer temperatures may increase for similar reasons, but averaged over the year a winter (and night-time) cooling dominates, which is attributable to lower roughness upon deforestation reducing the mixing in of warm air from the atmosphere aloft [46]. Deforestation in boreal regions also causes albedo to increase leading to a reduction in absorbed, available energy, the effect that is commonly assumed to be the major climate effect of boreal forest clearing; however, recent studies agree that the lower amount of absorbed energy locally is largely compensated for by reduced turbulent heat fluxes [13, 14, 46]. It becomes clear, therefore, that the common statement that albedo is the most important biogeophysical driver of LULCC effects holds only for global climate aspects [16], but not for local effects. Models continue to show wide divergence on the partitioning of turbulent heat exchange into sensible and latent fluxes (the "Bowen ratio"), identified for the previous generation of global climate models (LUCID [148]), for state-of-the-art models (CMIP6 [151]), and recently also in regional climate models [153]. New observations providing evaluation data [154] now make progress in improving the representation of turbulent heat exchange in models.

The earlier perception of boreal A/R being counter-productive for mitigation because albedo-induced warming may be stronger than $\mathrm{CO}_{2}$-induced cooling $[155,156]$ needs to be revisited given the recent findings of a dominance of nonradiative terms over albedo effects in both observations [13] and models [46] for local effects. Indeed, the albedo cooling 
becomes the dominant signal in most models when total (local and non-local) effects are considered [149], causing the temperature to decrease across most of the globe apart from the inner tropics for global large-scale and historical deforestation patterns [151]. This non-local albedo cooling has not been attributed to individual regions yet. It thus seems premature that assessments of CDR potentials (e.g., $[20,145])$ take out boreal regions entirely from $\mathrm{A} / \mathrm{R}$ considerations, in particular since the boreal albedo cooling, with a high importance of the "snow masking" effect, will become smaller under a warmer (and thus snow-poorer) climate.

Precipitation and other climatic effects are less well investigated compared to temperature responses. Precipitation typically decreases globally and over the deforested areas, in particular in the humid tropics, in model simulations of large-scale deforestation $[15,151]$. This is generally in line with a smaller-scale, observational evidence for Europe showing increased precipitation at the locations of forestation, though downwind effects show a seasonally and regionally more specific pattern [157]. Recent research confirmed that the effects of deforestation on precipitation in the Amazon are highly scale-dependent, with kilometer-scale LULCC increasing precipitation [158], but large-scale clearing decreasing it [159]. Due to the high rates of precipitation recycling, deforestation could induce a regional tipping point to a drier, savanna-like ecosystem state; this is warned of as being imminent at current deforestation rates [160], but the IPCC's assessment is of low confidence that such a change, driven by deforestation and climate change-induced drying, occurs in the twenty-first century [161]. Models also suggest remote effects of large-scale deforestation on monsoon regions, in particular of high-latitude LULCC due to impacts on meridional heat transport [162]. The detection of a robust signal from deforestation for temperature or precipitation takes decades or requires large areas of removed forest cover, in particular when the non-local effects (which contain weather noise [15]) are included, so in general longer temporal scales and larger spatial extent than current policy decision horizons [151]. This problem of signal detection is likely aggravated for $\mathrm{A} / \mathrm{R}$ with its long timescales of regrowth, which will make it more difficult to draw political awareness to $\mathrm{A} / \mathrm{R}$ as a potential land use strategy with large climatic benefit.

In light of choosing specific LULCC practices for climate mitigation and adaptation, progress is necessary for understanding the effects of the various types of LULCC transitions. Observational datasets started to provide such splits $[13,14]$, but information on all transitions depicted in Fig. 1 is far from complete; more research on individual land management practices is needed. Luyssaert et al. [1] showed that land management and land cover change impact the surface temperature with a similar magnitude, with land management covering twice the area compared to land use-induced land cover changes. Integration of land management practices in models has thus become a key priority (Fig. 1 [2]). Erb et al. [163] attributed large biogeophysical effects to the land use practices "harvest" (of forest and crops) and the two more recent model developments "cropland irrigation" and "choice of forest species." While consorted model intercomparisons of land management practices have been initiated [24], individual studies suggest that irrigation at current levels has particularly strong effects during hot and dry extremes, cooling the irrigated land by $0.8 \mathrm{~K}$ on average on the hottest day of the year [164], with around one billion people benefitting from these dampened extreme weather conditions [165]. The effects on annual mean temperature are uncertain, with studies finding only minor impact on near-surface air temperature [164], but a change on the order of $1 \mathrm{~K}$ for surface temperature [13]. Although the monsoon precipitation in the heavily irrigated South and Southeast Asian region may have been decreased by the reduced landsea temperature contrast due to cooling by irrigation ([164, 166], and references therein), severely dry months may also have decreased in number [166] and advective moisture transport and changes in regional circulations may have increased precipitation over regions not directly subject to irrigation such as Eastern Africa [167]. Similarly, individual observational studies suggest large biogeophysical effects for tree species selection, with an annual mean warming typically below $0.5 \mathrm{~K}$ for conversion of broadleaf deciduous to needleleaf evergreen forest in all regions of the world [13], attributable mostly to albedo changes [13] and associated with an energy shift from latent to sensible heat fluxes [14]. In Europe, broadleaf trees may mitigate hot extremes [168] and their conversion over the last centuries contributed to the conclusion that European forest management has not mitigated climate change historically [169].

The strength of biogeophysical effects is highly dependent on the future scenario for several reasons: (i) As albedoand snow-related cooling of deforestation diminishes in a warmer climate and LULCC-related decreases in turbulent heat fluxes may become stronger in other regions, the biogeophysical local warming will likely increase in the future $[170,171]$; the relevance of background climate can also be inferred from today's latitudinally differentiated climate response to LULCC [172]. (ii) Meanwhile, substantial parts of the world have experienced greening trends (increases in leaf area) in recent decades, with particular hotspots related to land management in China (mainly on forests and croplands) and India (mainly on croplands [173-175]); this will alter the strengths of surface energy balance changes for related LULCC conversions. (iii) For many regions, the temperature response may be strongest when starting deforestation from low forest cover fractions [171] (mixed evidence across models in Boysen et al. [151]), an effect that further agricultural expansion will enhance. (iv) LULCC effects will 
become more important in relative terms, when fossil-fuel emissions decrease; e.g., Hirsch et al. [176] showed that comparing a 1.5 to $2{ }^{\circ} \mathrm{C}$ climate target, changes in temperature extremes may be more strongly influenced by LULCC than the climate target.

LULCC may further affect climate by changes in biogenic volatile organic compound emissions, which contribute to the formation of secondary organic aerosols with consequences on cloud formation and radiative fluxes and influence $\mathrm{CH}_{4}$ lifetime and $\mathrm{O}_{3}$ formation. For instance, forest clearing has led to decreases in isoprene and monoterpene emissions [177]. Agriculture expansion increases dust formation via wind erosion, which may alter the radiative budget [178], as does smoke from biomass burning and altered fire regimes; Heald and Spracklen [179] provided a review of LULCC effects on air chemistry, but the scarcity of recent global assessments makes this topic outside the scope of our study.

\section{Spotlight: Can We Reconcile the Seemingly Contradicting Results of Models and Observations Concerning the Cooling Effect of High-Latitude Deforestation?}

Early modeling studies suggested that large-scale deforestation leads to cooling in the temperate and boreal regions and concluded that boreal $\mathrm{A} / \mathrm{R}$ may be counter-productive to mitigation efforts [155]. They attributed the cooling effect to the increased surface albedo of replacing dark forests with agricultural land, enhanced by "snow masking" [180]. More recent observation-based assessments [13, 14] agree with models that deforestation leads to surface warming in the tropics, but they show warming also in temperate and parts of the boreal regions, where models showed cooling. They further found that the cooling effect of forests results from non-radiative (roughness) changes rather than albedo changes-even in the high latitudes [13]. Here we resolve both apparent discrepancies (more widespread cooling from deforestation and higher importance of albedo in models as compared to observations) by the fact that observations capture only local temperature effects but exclude non-local effects-for example, when measurements of neighboring forests and grasslands are compared, any non-local effects cancel, because advection and atmospheric circulation affect neighboring regions similarly.

Splitting local from non-local biogeophysical effects of deforestation by a checkerboard setup in an Earth system model, Winckler et al. [149] have shown that the non-local signal of deforestation constitutes a widespread cooling signal across boreal and temperate regions, while the local effects show a warming in the temperate regions and smaller cooling in the boreal. The non-local effects exceeded the globally averaged local warming signal by a factor of three in their model. The dominance of non-local effects was found robust across several models. The different spatial patterns of local and non-local effects were later confirmed by comparing land-only simulations to simulations coupled to the atmosphere [42]. The apparent discrepancy of temperate and boreal cooling from deforestation in models to temperate and, partly, boreal warming in observations is thus attributable to non-local effects being excluded from observation-derived estimates.

The fact that models attribute biogeophysically induced temperature change more to albedo changes in the high-latitudes, while observations attribute them to non-radiative processes, can also be attributed to the inclusion of non-local effects in model simulations but not in observations. Earlier studies often inferred indirectly from a strong decrease in absorbed short-wave radiation following deforestation to a large importance of albedo for the climate. While albedo clearly influences absorption of short-wave radiation, this does not necessarily impact temperatures: Reduced turbulent heat loss due to the smoother surface may compensate for the cooling from reduced net short-wave radiation. That this is the case for deforestation has been proposed by models for local effects [46] (see Biogeophysical Effects). While albedo dominates the temperature signal for non-local processes [46], roughness dominates local temperature changes [13].

A further explanation for the discrepancy between models and observations concerning which regions are cooled or warmed by forest cover changes may lie in inconsistent variables (Fig. 3): Earlier model studies usually reported only near-surface air temperature $\left(\mathrm{T}_{2 \mathrm{~m}}\right)$ as measured by weather stations and Fluxnet towers, while studies based on remote sensing data report effects on surface temperature $\left(\mathrm{T}_{\text {surf }}\right)$ $[150,181] . \mathrm{T}_{2 \mathrm{~m}}$ typically shows a smaller local response to deforestation than $\mathrm{T}_{\text {surf }}$. While the annual mean cooling from deforestation stretches south to $35^{\circ} \mathrm{N}$ for $\mathrm{T}_{2 \mathrm{~m}}$, it ends at $45-55^{\circ} \mathrm{N}$ for $\mathrm{T}_{\text {surf }}[150]$. This difference may also explain why satellite-based studies such as Duveiller et al. [14] found less cooling in temperate/boreal latitudes than studies based on observations of air temperature from weather stations and Fluxnet towers [182].

In summary, although both Earth system models [4] and observations [152] differ among themselves in terms of the exact size of temperature changes, they are generally consistent with each other concerning the spatial patterns of cooling or warming when their different scopes concerning non-local effects are taken into account. While local effects of LULCC are relevant for local living conditions, LULCC as a mitigation tool needs to consider non-local effects as well. While local effects are known to change with background climate such as future climate change [171], they have been shown to be largely independent of the extent of global LULCC [15]. However, non-local effects are dependent on the global scenario of LULCC as atmospheric circulation changes respond 


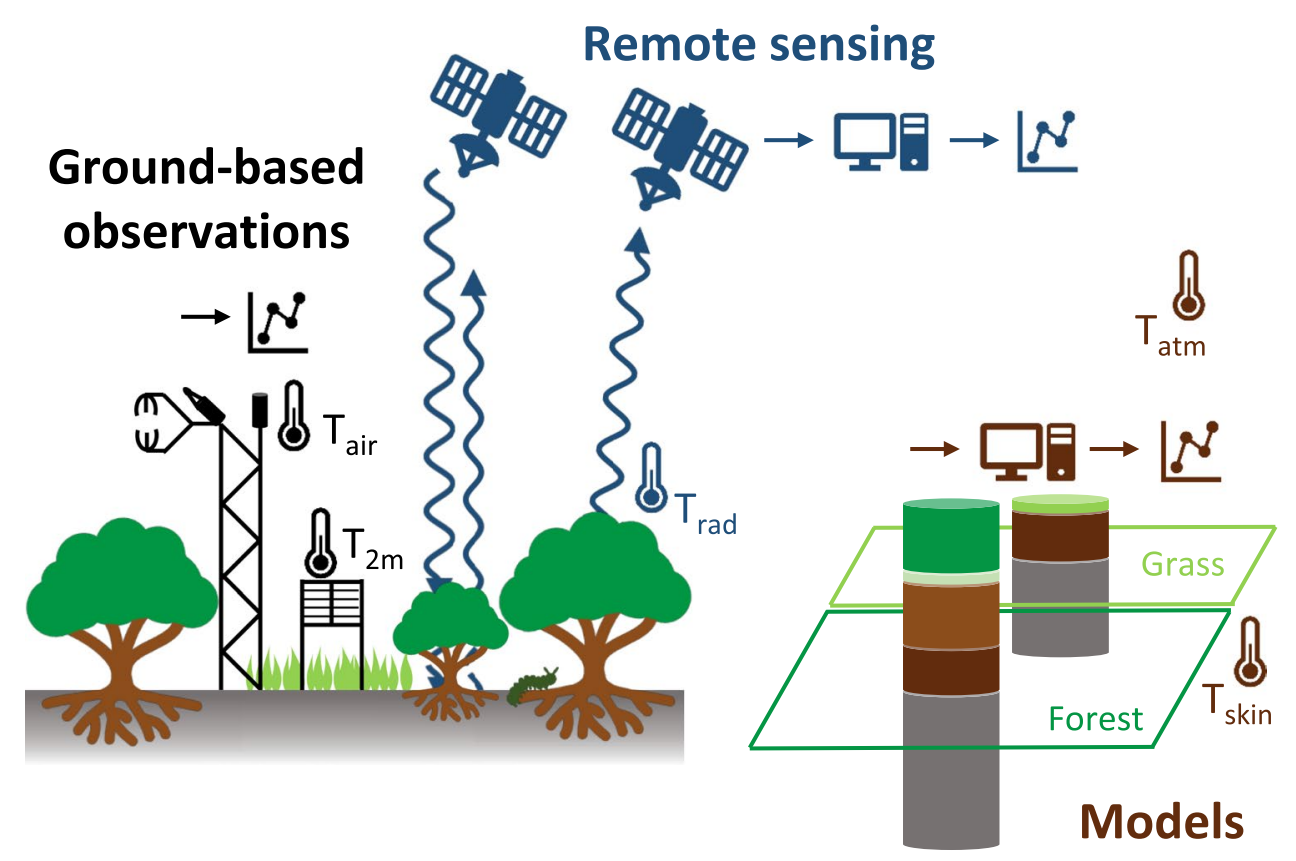

Fig. 3 Different methods allow us to cross-check estimates of LULCC effects: (1) ground-based methods, such as weather stations, eddy covariance measurements, or forest inventories (depicted in black); (2) remote sensing (blue); (3) land surface modeling (brown). When comparing different methods, it needs to be considered that variables may be inconsistently defined. This is exemplified here for temperatures: weather stations measure temperature at $2 \mathrm{~m}$ height
$\left(\mathrm{T}_{2 \mathrm{~m}}\right)$ while eddy towers often measure it higher up $\left(\mathrm{T}_{\text {air }}\right)$; models output only temperature at skin $\left(\mathrm{T}_{\text {skin }}\right)$ and in the lowest atmospheric layer $\left(\mathrm{T}_{\mathrm{atm}}\right)$, and satellites measure radiometric surface temperature $\left(\mathrm{T}_{\mathrm{rad}}\right)$. Models are coarse (in terms of process detail and spatial resolution) but spatially comprehensive representations of reality. Satellite estimates also rely heavily on model assumptions to derive water, energy, or greenhouse gas fluxes from radiometric information to LULCC worldwide; this complicates the inclusion of nonlocal effects in national or local LULCC decision-making and only local effects are currently proposed to be included in policies [5], leaving the integration of non-local effects into policy as an emerging field.

We conclude from our review that more evidence and better process understanding emerged for the biogeophysical effects. Robust features are a warming in both tropical and temperate regions when only local effects of deforestation are considered, and new evidence for altered precipitation locally and remotely emerged for several regions. The large model spread can now be addressed through evaluation against an increasing number of observational datasets. General agreement between models and observations calls for the inclusion of local climate effects in policy-making.

\section{Conclusions and Outlook}

It is evident that LULCC plays a crucial role in future climate policies: LULCC emissions (currently $25 \%$ of all anthropogenic GHG emissions, see Biogeochemical Effects) need to be reduced as part of the larger mitigation efforts to achieve the Paris Agreement's goals, which will require massive structural changes $[183,184]$. With the most readily available and best-researched CDR methods, LULCC is in the spotlight for bearing the brunt of required negative emissions until technological solutions have been scaled up [3]. The land sector's sustainable contribution to the global mitigation needed in 2050 for a $1.5^{\circ} \mathrm{C}$ target has been estimated to about $30 \%$ or $15 \mathrm{GtCO}_{2} \mathrm{e}$ year $^{-1}$ [147], roughly half of which is attributable each to emissions reductions and CDR. Managed land further is a massive natural sink for $\mathrm{CO}_{2}$ - recognized by official country reporting under UNFCCC, although global carbon cycle models show that part of this sink is not attributable to changes in land use activities, but to natural changes in environmental conditions (see Spotlight: Why Are Uncertainties in LULCC-Related GHG Fluxes so Large?).

However, protecting, restoring, or sustainably managing ecosystem services with the goal of mitigating climate change, as "natural climate solutions" and "nature-based solutions" imply [20], needs to integrate these biogeochemical aspects with biogeophysical ones, as well with other ecosystem services (which are outside the scope of this study). The first task is to ensure that the goal of mitigating global climate change is not compromised by biogeophysical effects, which via advection and circulation changes may affect remote areas (see Biogeophysical Effects). The second task is to carefully consider trade-offs and ideally create 
co-benefits between the global scale of mitigation and local climate change relevant for living conditions. As LULCC has the potential to alter local mean temperatures up to several degrees and strongly mitigate heat extremes (see Biogeophysical Effects), targeted LULCC may be an efficient way to adapt to global climate change [185]. In order to assess mitigation and adaptation together, the challenge for future research on LULCC will lie in keeping the global perspective and regional setting of LULCC that determines non-local effects [149, 186], while moving to the fine scales at which micro- and meso-scale dependencies are resolved (including, e.g., precipitation increases for small-scale tropical deforestation) $[187,188]$ - possibilities that may open with creating a "digital twin" of Earth [189]. It is these fine scales, too, at which any LULCC practice is implemented and at which it can be sustainably maintained.

Another emerging strand of future research will thus focus on the integration of human decision-making and natural systems. LULCC has been identified as one of the most important reasons for strengthening the integration of socioeconomic and Earth system modeling [190], and the first approaches to capture feedbacks between management input, productivity, prices, and climate have been developed $[191,192]$. The future will likely see a move towards the finer scales in this field as well, to capture individual behavior and decision-making [193].

Funding Open Access funding enabled and organized by Projekt DEAL. F.H. and S.G. were funded by the Federal Ministry of Education and Research under the JPI Climate Axis project Land Management and Climate (LAMACLIMA); S.B. was funded by the German Stifterverband für die Deutsche Wissenschaft e.V. in collaboration with Volkswagen AG.

\section{Declarations}

Conflict of Interest The authors declare no conflicts of interest.

Human and Animal Rights and Informed Consent This article does not contain any studies with human or animal subjects performed by any of the authors.

Open Access This article is licensed under a Creative Commons Attribution 4.0 International License, which permits use, sharing, adaptation, distribution and reproduction in any medium or format, as long as you give appropriate credit to the original author(s) and the source, provide a link to the Creative Commons licence, and indicate if changes were made. The images or other third party material in this article are included in the article's Creative Commons licence, unless indicated otherwise in a credit line to the material. If material is not included in the article's Creative Commons licence and your intended use is not permitted by statutory regulation or exceeds the permitted use, you will need to obtain permission directly from the copyright holder. To view a copy of this licence, visit http://creativecommons.org/licenses/by/4.0/.

\section{References}

1. Luyssaert S, Jammet M, Stoy PC, Estel S, Pongratz J, Ceschia $\mathrm{E}$, et al. Land management and land-cover change have impacts of similar magnitude on surface temperature. Nat Clim Chang. 2014;4(5):389-93. https://doi.org/10.1038/nclimate2196.

2. Pongratz J, Dolman H, Don A, Erb KH, Fuchs R, Herold M, et al. Models meet data: Challenges and opportunities in implementing land management in Earth system models. Glob Chang Biol. 2018;24(4):1470-87. https://doi.org/10.1111/gcb.13988.

3. Fuss S, Lamb WF, Callaghan MW, Hilaire J, Creutzig F, Amann $\mathrm{T}$ et al. Negative emissions-Part 2: Costs, potentials and side effects. Environ Res Lett. 2018;13(6). https://doi.org/10.1088/ 1748-9326/aabf9f

4. Jia G, Shevliakova E, Artaxo P, De Noblet-Ducoudré N, Houghton R, House J, Kitajima K, Lennard C, A Popp, Sirin A, Sukumar R, Verchot L. Land-climate interactions. In: Climate Change and Land: an IPCC special report on climate change, desertification, land degradation, sustainable land management, food security, and greenhouse gas fluxes in terrestrial ecosystems [P.R. Shukla, J. Skea, E. Calvo Buendia, V. Masson-Delmotte, H.-O. Pörtner, D.C. Roberts, P. Zhai, R. Slade, S. Connors, R. van Diemen, M. Ferrat, E. Haughey, S. Luz, S. Neogi, M. Pathak, J. Petzold, J. Portugal Pereira, P. Vyas, E. Huntley, K. Kissick, M, Belkacemi, J. Malley, (eds.)]. 2019.

5. Duveiller G, Caporaso L, Abad-Viñas R, Perugini L, Grassi G, Arneth A et al. Local biophysical effects of land use and land cover change: towards an assessment tool for policy makers. Land Use Policy. 2020;91. https://doi.org/10.1016/j.landusepol. 2019.104382

6. Bonan G. Climate change and terrestrial ecosystem modeling. Cambridge: Cambridge University Press; 2019.

7. Carlson KM, Gerber JS, Mueller ND, Herrero M, MacDonald GK, Brauman KA, et al. Greenhouse gas emissions intensity of global croplands. Nat Clim Chang. 2016;7(1):63-8. https://doi. org/10.1038/nclimate3158.

8. Hong C, Burney JA, Pongratz J, Nabel J, Mueller ND, Jackson $\mathrm{RB}$, et al. Global and regional drivers of land-use emissions in 1961-2017. Nature. 2021;589(7843):554-61. https://doi.org/10. 1038/s41586-020-03138-y.

9. Ciais P, Sabine C, Bala G, Bopp L, Brovkin V, Canadell J et al. Carbon and Other Biogeochemical Cycles. In: Climate Change 2013: The Physical Science Basis. Contribution of Working Group I to the Fifth Assessment Report of the Intergovernmental Panel on Climate Change [Stocker, T.F., D. Qin, G.-K. Plattner, M. Tignor, S.K. Allen, J. Boschung, A. Nauels, Y. Xia, V. Bex and P.M. Midgley (eds.)]. Cambridge University Press, Cambridge, United Kingdom and New York, NY, USA.

10. Friedlingstein P, O'Sullivan M, Jones MW, Andrew RM, Hauck J, Olsen A, et al. Global Carbon Budget 2020. Earth Sys Sci Data. 2020;12(4):3269-340. https://doi.org/10.5194/ essd-12-3269-2020.

11. Tian H, Xu R, Canadell JG, Thompson RL, Winiwarter W, Suntharalingam $\mathrm{P}$, et al. A comprehensive quantification of global nitrous oxide sources and sinks. Nature. 2020;586(7828):248-56. https://doi.org/10.1038/s41586-020-2780-0.

12. Saunois M, Stavert AR, Poulter B, Bousquet P, Canadell JG, Jackson RB, et al. The global methane Budget 2000-2017. Earth Syst Sci Data. 2020;12(3):1561-623. https://doi.org/10.5194/ essd-12-1561-2020.

13. Bright RM, Davin E, O'Halloran T, Pongratz J, Zhao K, Cescatti A. Local temperature response to land cover and management change driven by non-radiative processes. Nat Clim Chang. 2017;7(4):296-302. https://doi.org/10.1038/nclimate3250. 
14. Duveiller G, Hooker J, Cescatti A. The mark of vegetation change on Earth's surface energy balance. Nat Commun. 2018;9(1):679. https://doi.org/10.1038/s41467-017-02810-8.

15. Winckler J, Reick CH, Pongratz J. Robust identification of local biogeophysical effects of land-cover change in a global climate model. J Clim. 2017;30(3):1159-76. https://doi.org/10.1175/ jcli-d-16-0067.1.

16. Gulev SK, P. W. Thorne, J. Ahn, F. J. Dentener, C. M. Domingues, S. Gerland, D. Gong, D. S. Kaufman, H. C. Nnamchi, J. Quaas, J. A. Rivera, S. Sathyendranath, S. L. Smith, B. Trewin, K. von Shuckmann, R. S. Vose. Changing State of the Climate System. In: Masson-Delmotte V, P. Zhai, A. Pirani, S. L. Connors, C. Péan, S. Berger, N. Caud, Y. Chen, L. Goldfarb, M. I. Gomis, M. Huang, K. Leitzell, E. Lonnoy, J. B. R. Matthews, T. K. Maycock, T. Waterfield, O. Yelekçi, R. Yu and B. Zhou, editor. Climate change 2021: The Physical Science Basis. Contribution of Working Group I to the Sixth Assessment Report of the Intergovernmental Panel on Climate Change: Cambridge University Press. In Press; 2021.

17. Canadell Josep G. JG, P. M. S. Monteiro, M. H. Costa, L. Cotrim da Cunha, P. M. Cox, A. V. Eliseev, S. Henson, M. Ishii, S. Jaccard, C. Koven, A. Lohila, P. K. Patra, S. Piao, J. Rogelj, S. Syampungani, S. Zaehle, K. Zickfeld. Global Carbon and other Biogeochemical Cycles and Feedbacks. In: Masson-Delmotte V, P. Zhai, A. Pirani, S. L. Connors, C. Péan, S. Berger, N. Caud, Y. Chen, L. Goldfarb, M. I. Gomis, M. Huang, K. Leitzell, E. Lonnoy, J.B.R. Matthews, T. K. Maycock, T. Waterfield, O. Yelekçi, R. Yu and B. Zhou, editor. Climate change 2021: The Physical Science Basis. Contribution of Working Group I to the Sixth Assessment Report of the Intergovernmental Panel on Climate Change: Cambridge University Press. In Press; 2021.

18. Eyring V, Bony S, Meehl GA, Senior CA, Stevens B, Stouffer RJ, et al. Overview of the Coupled Model Intercomparison Project Phase 6 (CMIP6) experimental design and organization. Geosci Model Dev. 2016;9(5):1937-58. https://doi.org/10.5194/ gmd-9-1937-2016.

19. Foley JA, Ramankutty N, Brauman KA, Cassidy ES, Gerber JS, Johnston M, et al. Solutions for a cultivated planet. Nature. 2011;478(7369):337-42. https://doi.org/10.1038/nature10452.

20. Griscom BW, Adams J, Ellis PW, Houghton RA, Lomax G, Miteva DA, et al. Natural climate solutions. Proc Natl Acad Sci U S A. 2017;114(44):11645-50. https://doi.org/10.1073/pnas. 1710465114.

21. Mori AS, Dee LE, Gonzalez A, Ohashi H, Cowles J, Wright AJ, et al. Biodiversity-productivity relationships are key to naturebased climate solutions. Nat Clim Chang. 2021;11(6):543-50. https://doi.org/10.1038/s41558-021-01062-1.

22. Petrescu AMR, Peters GP, Janssens-Maenhout G, Ciais P, Tubiello FN, Grassi G, et al. European anthropogenic AFOLU greenhouse gas emissions: a review and benchmark data. Earth Syst Sci Data. 2020;12(2):961-1001. https://doi.org/10.5194/ essd-12-961-2020.

23. Pongratz J, Reick CH, Houghton RA, House JI. Terminology as a key uncertainty in net land use and land cover change carbon flux estimates. Earth Syst Dyn. 2014;5(1):177-95. https://doi. org/10.5194/esd-5-177-2014.

24. Lawrence DM, Hurtt GC, Arneth A, Brovkin V, Calvin KV, Jones AD, et al. The Land Use Model Intercomparison Project (LUMIP) contribution to CMIP6: rationale and experimental design. Geosci Model Dev. 2016;9(9):2973-98. https://doi.org/ 10.5194/gmd-9-2973-2016.

25. Obermeier WA, Nabel JEMS, Loughran T, Hartung K, Bastos A, Havermann F, et al. Modelled land use and land cover change emissions - a spatio-temporal comparison of different approaches. Earth Syst Dyn. 2021;12(2):635-70. https://doi.org/ 10.5194/esd-12-635-2021.

26. Tian H, Yang J, Lu C, Xu R, Canadell JG, Jackson RB, et al. The Global N2O Model Intercomparison Project. Bull Am Meteor Soc. 2018;99(6):1231-51. https://doi.org/10.1175/ bams-d-17-0212.1.

27. Blyth EM, Arora VK, Clark DB, Dadson SJ, De Kauwe MG, Lawrence DM, et al. Advances in land surface modelling. Curr Clim Change Rep. 2021;7(2):45-71. https://doi.org/10.1007/ s40641-021-00171-5.

28. Gasser T, Crepin L, Quilcaille Y, Houghton RA, Ciais P, Obersteiner M. Historical $\mathrm{CO}_{2}$ emissions from land use and land cover change and their uncertainty. Biogeosciences. 2020;17(15):4075101. https://doi.org/10.5194/bg-17-4075-2020.

29. Hansis E, Davis SJ, Pongratz J. Relevance of methodological choices for accounting of land use change carbon fluxes. Global Biogeochem Cycles. 2015;29(8):1230-46. https://doi.org/10. 1002/2014gb004997.

30. Houghton RA, Nassikas AA. Global and regional fluxes of carbon from land use and land cover change 1850-2015. Global Biogeochem Cycles. 2017;31(3):456-72. https://doi.org/10.1002/ $2016 \mathrm{gb} 005546$.

31. Davis SJ, Burney JA, Pongratz J, Caldeira K. Methods for attributing land-use emissions to products. Carbon Management. 2014;5(2):233-45. https://doi.org/10.1080/17583004.2014. 913867.

32. Thompson RL, Lassaletta L, Patra PK, Wilson C, Wells KC, Gressent A, et al. Acceleration of global $\mathrm{N}_{2} \mathrm{O}$ emissions derived from atmosphericseen from two decades of atmospheric inversion. Nat Clim Chang. 2019;9(12):993-8. https://doi.org/10. 1038/s41558-019-0613-7.

33. Fujita R, Morimoto S, Maksyutov S, Kim HS, Arshinov M, Brailsford $\mathrm{G}$ et al. Global and regional CH4 emissions for 19952013 derived from atmospheric $\mathrm{CH}_{4}, \delta 13 \mathrm{C}_{-} \mathrm{CH}_{4}$, and $\mathrm{SD}-\mathrm{CH} 4$ observations and a chemical transport model. J Geophys Res Atmos. 2020; 125(14). https://doi.org/10.1029/2020jd032903

34. Palmer PI, Feng L, Baker D, Chevallier F, Bosch H, Somkuti P. Net carbon emissions from African biosphere dominate pantropical atmospheric $\mathrm{CO}_{2}$ signal. Nat Commun. 2019;10(1):3344. https://doi.org/10.1038/s41467-019-11097-w.

35. Arora VK, Katavouta A, Williams RG, Jones CD, Brovkin V, Friedlingstein $\mathrm{P}$, et al. Carbon-concentration and carbon-climate feedbacks in CMIP6 models and their comparison to CMIP5 models. Biogeosciences. 2020;17(16):4173-222. https://doi.org/ 10.5194/bg-17-4173-2020.

36. Pitman AJ, de Noblet-Ducoudré N, Cruz FT, Davin EL, Bonan $\mathrm{GB}$, Brovkin $\mathrm{V}$ et al. Uncertainties in climate responses to past land cover change: first results from the LUCID intercomparison study. Geophys Res Lett. 2009; 36(14). https://doi.org/10.1029/ 2009g1039076

37. Boysen LR, Brovkin V, Arora VK, Cadule P, de Noblet-Ducoudré $\mathrm{N}$, Kato E, et al. Global and regional effects of land-use change on climate in 21 st century simulations with interactive carbon cycle. Earth Syst Dyn. 2014;5(2):309-19. https://doi.org/10. 5194/esd-5-309-2014.

38. Lejeune Q, Seneviratne SI, Davin EL. Historical land-cover change impacts on climate: comparative assessment of LUCID and CMIP5 multimodel experiments. J Clim. 2017;30(4):143959. https://doi.org/10.1175/jcli-d-16-0213.1.

39. Brovkin V, Boysen L, Arora VK, Boisier JP, Cadule P, Chini L, et al. Effect of anthropogenic land-use and land-cover changes on climate and land carbon storage in CMIP5 projections for the twenty-first century. J Clim. 2013;26(18):6859-81. https://doi. org/10.1175/jcli-d-12-00623.1. 
40. Kumar S, Dirmeyer PA, Merwade V, DelSole T, Adams JM, Niyogi D. Land use/cover change impacts in CMIP5 climate simulations: a new methodology and 21st century challenges. J Geophys Res Atmos. 2013;118(12):6337-53. https://doi.org/10. 1002/jgrd.50463.

41. Malyshev S, Shevliakova E, Stouffer RJ, Pacala SW. Contrasting local versus regional effects of land-use-change-induced heterogeneity on historical climate: analysis with the GFDL Earth system model. J Clim. 2015;28(13):5448-69. https://doi.org/10. 1175/jcli-d-14-00586.1.

42. Chen L, Dirmeyer PA. Reconciling the disagreement between observed and simulated temperature responses to deforestation. Nat Commun. 2020;11(1):202. https://doi.org/10.1038/ s41467-019-14017-0.

43. Devaraju N, de Noblet-Ducoudré N, Quesada B, Bala G. Quantifying the relative importance of direct and indirect biophysical effects of deforestation on surface temperature and teleconnections. J Clim. 2018;31(10):3811-29. https://doi.org/10.1175/ jcli-d-17-0563.1.

44. Juang J-Y, Katul G, Siqueira M, Stoy P, Novick K. Separating the effects of albedo from eco-physiological changes on surface temperature along a successional chronosequence in the southeastern United States. Geophys Res Lett. 2007; 34(21) https:// doi.org/10.1029/2007gl031296

45. Chen L, Dirmeyer PA. Adapting observationally based metrics of biogeophysical feedbacks from land cover/land use change to climate modeling. Environ Res Lett. 2016; 11(3) https://doi.org/ 10.1088/1748-9326/11/3/034002

46. Winckler J, Reick CH, Bright RM, Pongratz J. Importance of surface roughness for the local biogeophysical effects of deforestation. J Geophys Res Atmos. 2019;124(15):8605-18. https:// doi.org/10.1029/2018jd030127.

47. Davin EL, de Noblet-Ducoudré N. Climatic impact of globalscale deforestation: radiative versus nonradiative processes. J Clim. 2010;23(1):97-112. https://doi.org/10.1175/2009jcli31 02.1 .

48. Fan L, Wigneron JP, Ciais P, Chave J, Brandt M, Fensholt R, et al. Satellite-observed pantropical carbon dynamics. Nat Plants. 2019;5(9):944-51. https://doi.org/10.1038/s41477-019-0478-9.

49. Tagesson T, Schurgers G, Horion S, Ciais P, Tian F, Brandt $\mathrm{M}$, et al. Recent divergence in the contributions of tropical and boreal forests to the terrestrial carbon sink. Nat Ecol Evol. 2020;4(2):202-9. https://doi.org/10.1038/s41559-019-1090-0.

50. Harris NL, Gibbs DA, Baccini A, Birdsey RA, de Bruin S, Farina $\mathrm{M}$, et al. Global maps of twenty-first century forest carbon fluxes. Nat Clim Chang. 2021;11(3):234-40. https://doi.org/10.1038/ s41558-020-00976-6.

51. Baccini A, Walker W, Carvalho L, Farina M, Sulla-Menashe D, Houghton RA. Tropical forests are a net carbon source based on aboveground measurements of gain and loss. Science. 2017;358(6360):230-4. https://doi.org/10.1126/science.aam59 62.

52. Maxwell SL, Evans T, Watson JEM, Morel A, Grantham H, Duncan A, et al. Degradation and forgone removals increase the carbon impact of intact forest loss by 626. Sci Adv. 2019;5(10):eaax2546. https://doi.org/10.1126/sciadv.aax2546.

53. Qin Y, Xiao X, Wigneron J-P, Ciais P, Brandt M, Fan L, et al. Carbon loss from forest degradation exceeds that from deforestation in the Brazilian Amazon. Nat Clim Chang. 2021;11(5):4428. https://doi.org/10.1038/s41558-021-01026-5.

54. Wang Q, Zhou F, Shang Z, Ciais P, Winiwarter W, Jackson RB, et al. Data-driven estimates of global nitrous oxide emissions from croplands. Natl Sci Rev. 2019;7(2):441-52. https://doi.org/ 10.1093/nsr/nwz087.
55. IPCC. 2006 IPCC Guidelines for National Greenhouse Gas Inventories, Prepared by the National Greenhouse Gas Inventories Programme, Eggleston HS, Buendia L, Miwa K, Ngara T,d Tanabe K. (eds). Published: IGES, Japan. 2006.

56. FAO. From reference levels to results reporting: REDD+ under the United Nations Framework Convention on Climate Change. 2019.

57. Tubiello FN, Conchedda G, Wanner N, Federici S, Rossi S, Grassi G. Carbon emissions and removals from forests: new estimates, 1990-2020. Earth Syst Sci Data. 2021;13(4):1681-91. https://doi.org/10.5194/essd-13-1681-2021.

58. Tubiello FN, Salvatore M, Rossi S, Ferrara A, Fitton N, Smith P. The FAOSTAT database of greenhouse gas emissions from agriculture. Environ Res Lett. 2013; 8(1) https://doi.org/10.1088/ 1748-9326/8/1/015009

59. Li Y, Zhao M, Motesharrei S, Mu Q, Kalnay E, Li S. Local cooling and warming effects of forests based on satellite observations. Nat Commun. 2015;6:6603. https://doi.org/10.1038/ ncomms 7603 .

60. Alkama R, Cescatti A. Biophysical climate impacts of recent changes in global forest cover. Science. 2016;351(6273):600-4. https://doi.org/10.1126/science.aac8083.

61. Tyukavina A, Baccini A, Hansen MC, Potapov PV, Stehman $\mathrm{SV}$, Houghton RA et al. Aboveground carbon loss in natural and managed tropical forests from 2000 to 2012. Environ Res Lett. 2015;10(7) https://doi.org/10.1088/1748-9326/10/7/074002

62. Saatchi SS, Harris NL, Brown S, Lefsky M, Mitchard ET, Salas W, et al. Benchmark map of forest carbon stocks in tropical regions across three continents. Proc Natl Acad Sci U S A. 2011;108(24):9899-904. https://doi.org/10.1073/pnas.10195 76108.

63. Federici S, Grassi G, Harris N, Lee D, Neeff T, Penman J et al. GHG fluxes from forests - an assessment of national GHG estimates and independent research in the context of the Paris Agreement. 2017.

64. Xu Q, Man A, Fredrickson M, Hou Z, Pitkänen J, Wing B, et al. Quantification of uncertainty in aboveground biomass estimates derived from small-footprint airborne LiDAR. Remote Sens Environ. 2018;216:514-28. https://doi.org/10.1016/j.rse.2018. 07.022 .

65. Yanai R, Wayson C, Lee D, Espejo A, Campbell JL, Green MB, et al. Improving uncertainty in forest carbon accounting for REDD+ mitigation efforts. Environ Res Lett. 2020. https://doi. org/10.1088/1748-9326/abb96f.

66. Bullock EL, Woodcock CE, Souza C Jr, Olofsson P. Satellitebased estimates reveal widespread forest degradation in the Amazon. Glob Chang Biol. 2020;26(5):2956-69. https://doi.org/10. $1111 / \mathrm{gcb} .15029$.

67. Matricardi EAT, Skole DL, Costa OB, Pedlowski MA, Samek JH, Miguel EP. Long-term forest degradation surpasses deforestation in the Brazilian Amazon. Science. 2020;369(6509):137882. https://doi.org/10.1126/science.abb3021.

68. Gao Y, Skutsch M, Paneque-Gálvez J, Ghilardi A. Remote sensing of forest degradation: a review. Environ Res Lett. 2020; 15(10) https://doi.org/10.1088/1748-9326/abaad7

69. Hansen MC, Potapov PV, Moore R, Hancher M, Turubanova SA, Tyukavina A, et al. High-resolution global maps of 21st-century forest cover change. Science. 2013;342(6160):850-3. https://doi. org/10.1126/science.1244693.

70. INPE. PRODES (Deforestation). 2021. http://terrabrasilis.dpi. inpe.br/app/map/deforestation?hl=pt-br.

71. Almeida C, Maurano L, Valeriano D, Camara G, Vinhas L, Gomes A et al. Methodology for forest monitoring used in PRODES and DETER projects. Instituto Nacional de Pesquisas Espaciais (INPE). 2021. 
72. Tyukavina A, Hansen MC, Potapov PV, Stehman SV, SmithRodriguez K, Okpa C, et al. Types and rates of forest disturbance in Brazilian Legal Amazon, 2000-2013. Sci Adv. 2017;3(4):e1601047. https://doi.org/10.1126/sciadv.1601047.

73. Pearson TRH, Brown S, Casarim FM. Carbon emissions from tropical forest degradation caused by logging. Environ Res Lett. 2014; 9(3) https://doi.org/10.1088/1748-9326/9/3/034017

74. Longo M, Keller M, dos-Santos MN, Leitold V, Pinagé ER, Baccini $\mathrm{A}$, et al. Aboveground biomass variability across intact and degraded forests in the Brazilian Amazon. Global Biogeochem Cycles. 2016;30(11):1639-60. https://doi.org/10.1002/2016g b005465.

75. Rappaport DI, Morton DC, Longo M, Keller M, Dubayah R, dosSantos MN. Quantifying long-term changes in carbon stocks and forest structure from Amazon forest degradation. Environ Res Lett. 2018; 13(6) https://doi.org/10.1088/1748-9326/aac331

76. Xu L, Saatchi SS, Yang Y, Yu Y, Pongratz J, Bloom AA et al. Changes in global terrestrial live biomass over the 21 st century. Sci Adv. 2021; 7(27) https://doi.org/10.1126/sciadv.abe9829

77. Cook-Patton SC, Leavitt SM, Gibbs D, Harris NL, Lister $\mathrm{K}$, Anderson-Teixeira KJ, et al. Mapping carbon accumulation potential from global natural forest regrowth. Nature. 2020;585(7826):545-50. https://doi.org/10.1038/ s41586-020-2686-x.

78. Humphrey V, Berg A, Ciais P, Gentine P, Jung M, Reichstein M, et al. Soil moisture-atmosphere feedback dominates land carbon uptake variability. Nature. 2021;592(7852):65-9. https://doi.org/ 10.1038/s41586-021-03325-5.

79. Friedlingstein P, Jones MW, O'Sullivan M, Andrew RM, Bakker DCE, Hauck J, et al. Global carbon budget 2021. Earth Syst Sci Data Discuss. 2021;2021:1-191. https://doi.org/10.5194/ essd-2021-386.

80. Bayer AD, Fuchs R, Mey R, Krause A, Verburg PH, Anthoni P, et al. Diverging land-use projections cause large variability in their impacts on ecosystems and related indicators for ecosystem services. Earth Syst Dyn. 2021;12(1):327-51. https://doi.org/10. 5194/esd-12-327-2021.

81. Popp A, Calvin K, Fujimori S, Havlik P, Humpenöder F, Stehfest $\mathrm{E}$, et al. Land-use futures in the shared socio-economic pathways. Glob Environ Chang. 2017;42:331-45. https://doi.org/10.1016/j. gloenvcha.2016.10.002.

82. Hurtt GC, Chini L, Sahajpal R, Frolking S, Bodirsky BL, Calvin $\mathrm{K}$, et al. Harmonization of global land use change and management for the period 850-2100 (LUH2) for CMIP6. Geosci Model Dev. 2020;13(11):5425-64. https://doi.org/10. 5194/gmd-13-5425-2020.

83. Yu Z, Lu C, Tian H, Canadell JG. Largely underestimated carbon emission from land use and land cover change in the conterminous United States. Glob Chang Biol. 2019;25(11):374152. https://doi.org/10.1111/gcb.14768.

84. Winkler K, Fuchs R, Rounsevell M, Herold M. Global land use changes are four times greater than previously estimated. Nat Commun. 2021;12(1):2501. https://doi.org/10.1038/ s41467-021-22702-2.

85. FAO. FAOSTAT Statistical Database, domain Land Use. Available at: http://www.fao.org/faostat/en/\#data/RL. 2021.

86. FAO. Global forest resources assessment 2020: terms and definitions. Rome, Italy: Forest Resources Assessment Programme. 2020

87. Rosan TM, Klein Goldewijk K, Ganzenmüller R, O'Sullivan M, Pongratz J, Mercado LM, et al. A multi-data assessment of land use and land cover emissions from Brazil during 20002019. Environ Res Lett. 2021. https://doi.org/10.1088/17489326/ac08c3.

88. Chini L, Hurtt G, Sahajpal R, Frolking S, Klein Goldewijk $\mathrm{K}$, Sitch S, et al. Land-use harmonization datasets for annual global carbon budgets. Earth Syst Sci Data. 2021;13(8):417589. https://doi.org/10.5194/essd-13-4175-2021.

89. Di Vittorio AV, Mao J, Shi X, Chini L, Hurtt G, Collins WD. Quantifying the effects of historical land cover conversion uncertainty on global carbon and climate estimates. Geophys Res Lett. 2018;45(2):974-82. https://doi.org/10.1002/2017g 1075124.

90. Hartung K, Bastos A, Chini L, Ganzenmüller R, Havermann F, 1640 Hurtt GC, et al. Bookkeeping estimates of the net landuse change flux - a sensitivity study with the CMIP6 land-use dataset. Earth Syst Dynam. 2021;12:763-82. https://doi.org/10. 5194/esd-12-763-2021

91. Arneth A, Sitch S, Pongratz J, Stocker BD, Ciais P, Poulter $\mathrm{B}$, et al. Historical carbon dioxide emissions caused by landuse changes are possibly larger than assumed. Nat Geosci. 2017;10(2):79-84. https://doi.org/10.1038/ngeo2882.

92. Prestele R, Arneth A, Bondeau A, de Noblet-Ducoudré N, Pugh TAM, Sitch S, et al. Current challenges of implementing anthropogenic land-use and land-cover change in models contributing to climate change assessments. Earth Syst Dyn. 2017;8(2):36986. https://doi.org/10.5194/esd-8-369-2017.

93. Yang H, Ciais P, Santoro M, Huang Y, Li W, Wang Y, et al. Comparison of forest above-ground biomass from dynamic global vegetation models with spatially explicit remotely sensed observation-based estimates. Glob Chang Biol. 2020;26(7):39974012. https://doi.org/10.1111/gcb.15117.

94. Fisher RA, Koven CD. Perspectives on the future of land surface models and the challenges of representing complex terrestrial systems. J Adv Model Earth Syst. 2020;12(4) https://doi.org/10. 1029/2018ms001453

95. Goll DS, Brovkin V, Liski J, Raddatz T, Thum T, Todd-Brown KEO. Strong dependence of $\mathrm{CO}_{2}$ emissions from anthropogenic land cover change on initial land cover and soil carbon parametrization. Global Biogeochem Cycles. 2015;29(9):1511-23. https:// doi.org/10.1002/2014gb004988.

96. Bastos A, Hartung K, Nützel TB, Nabel JEMS, Houghton RA, Pongratz J. Comparison of uncertainties in land-use change fluxes from bookkeeping model parameterization. Earth Syst Dynam. 2021;12:745-62. https://doi.org/10.5194/ esd-12-745-2021

97. Li W, Ciais P, Peng S, Yue C, Wang Y, Thurner M, et al. Landuse and land-cover change carbon emissions between 1901 and 2012 constrained by biomass observations. Biogeosciences. 2017;14(22):5053-67. https://doi.org/10.5194/bg-14-5053-2017.

98. Lienert S, Joos F. A Bayesian ensemble data assimilation to constrain model parameters and land-use carbon emissions. Biogeosciences. 2018;15(9):2909-30. https://doi.org/10.5194/ bg-15-2909-2018.

99. Fisher RA, Koven CD, Anderegg WRL, Christoffersen BO, Dietze MC, Farrior CE, et al. Vegetation demographics in Earth system models: a review of progress and priorities. Glob Chang Biol. 2018;24(1):35-54. https://doi.org/10.1111/gcb.13910.

100. Pelletier J, Ramankutty N, Potvin C. Diagnosing the uncertainty and detectability of emission reductions for REDD + under current capabilities: an example for Panama. Environ Res Lett. 2011; 6(2) https://doi.org/10.1088/1748-9326/6/2/024005

101. FAO. FAOSTAT Statistical Database, domain Climate Change: Emissions Totals. 2020. http://www.fao.org/faostat/en/\#data/GT

102. Grassi G, House J, Kurz WA, Cescatti A, Houghton RA, Peters $\mathrm{GP}$, et al. Reconciling global-model estimates and country reporting of anthropogenic forest $\mathrm{CO}_{2}$ sinks. Nat Clim Chang. 2018;8(10):914-20. https://doi.org/10.1038/s41558-018-0283-x.

103. Grassi G, Stehfest E, Rogelj J, van Vuuren D, Cescatti A, House $\mathrm{J}$, et al. Critical adjustment of land mitigation pathways for assessing countries' climate progress. Nat 
Clim Chang. 2021;11(5):425-34. https://doi.org/10.1038/ s41558-021-01033-6.

104. Fritz S, See L, Carlson T, Haklay M, Oliver JL, Fraisl D, et al. Citizen science and the United Nations Sustainable Development Goals. Nat Sustain. 2019;2(10):922-30. https://doi.org/10.1038/ s41893-019-0390-3.

105. Riahi K, van Vuuren DP, Kriegler E, Edmonds J, O'Neill BC, Fujimori S, et al. The Shared Socioeconomic Pathways and their energy, land use, and greenhouse gas emissions implications: An overview. Glob Environ Chang. 2017;42:153-68. https://doi.org/ 10.1016/j.gloenvcha.2016.05.009.

106. Nabel JEMS, Naudts K, Pongratz J. Accounting for forest age in the tile-based dynamic global vegetation model JSBACH4 (4.20p7; git feature/forests) - a land surface model for the ICONESM. Geosci Model Dev. 2020;13(1):185-200. https://doi.org/ 10.5194/gmd-13-185-2020.

107. Peng B, Guan K, Chen M, Lawrence DM, Pokhrel Y, Suyker A, et al. Improving maize growth processes in the community land model: implementation and evaluation. Agric For Meteorol. 2018;250-251:64-89. https://doi.org/10.1016/j.agrformet.2017. 11.012 .

108. Peng B, Guan K, Tang J, Ainsworth EA, Asseng S, Bernacchi CJ, et al. Towards a multiscale crop modelling framework for climate change adaptation assessment. Nat Plants. 2020;6(4):338-48. https://doi.org/10.1038/s41477-020-0625-3.

109. Yokohata T, Kinoshita T, Sakurai G, Pokhrel Y, Ito A, Okada M, et al. MIROC-INTEG-LAND version 1: a global biogeochemical land surface model with human water management, crop growth, and land-use change. Geosci Model Dev. 2020;13(10):4713-47. https://doi.org/10.5194/gmd-13-4713-2020.

110. Collier N, Hoffman FM, Lawrence DM, Keppel-Aleks G, Koven $\mathrm{CD}$, Riley WJ, et al. The International Land Model Benchmarking (ILAMB) system: design, theory, and implementation. J Adv Model Earth Syst. 2018;10(11):2731-54. https://doi.org/10.1029/ $2018 \mathrm{~ms} 001354$.

111. Sitch S, Friedlingstein P, Gruber N, Jones SD, MurrayTortarolo G, Ahlström A, et al. Recent trends and drivers of regional sources and sinks of carbon dioxide. Biogeosciences. 2015;12(3):653-79. https://doi.org/10.5194/bg-12-653-2015.

112. Minx JC, Lamb WF, Andrew RM, Canadell JG, Crippa M, Döbbeling $\mathrm{N}$, et al. A comprehensive and synthetic dataset for global, regional, and national greenhouse gas emissions by sector 1970-2018 with an extension to 2019. Earth Syst Sci Data. 2021;13(11):5213-52. https://doi.org/10.5194/ essd-13-5213-2021.

113. Erb KH, Kastner T, Plutzar C, Bais ALS, Carvalhais N, Fetzel T, et al. Unexpectedly large impact of forest management and grazing on global vegetation biomass. Nature. 2018;553(7686):73-6. https://doi.org/10.1038/nature25138.

114. Loughran TF, Boysen L, Bastos A, Hartung K, Havermann F, $\mathrm{Li} \mathrm{H}$ et al. Past and future climate variability uncertainties in the global carbon budget using the MPI grand ensemble. Global Biogeochem Cycles. 2021;35:e2021GB007019. https://doi. org/ 10.1029/2021GB007019.

115. Yue C, Ciais P, Houghton RA, Nassikas AA. Contribution of land use to the interannual variability of the land carbon cycle. Nat Commun. 2020;11(1):3170. https://doi.org/10.1038/ s41467-020-16953-8.

116. Ito A, Hajima T, Lawrence DM, Brovkin V, Delire C, Guenet $\mathrm{B}$ et al. Soil carbon sequestration simulated in CMIP6-LUMIP models: implications for climatic mitigation. Environ Res Lett. 2020; 15(12) https://doi.org/10.1088/1748-9326/abc912

117. Deng L, Zhu G-Y, Tang Z-S. Shangguan Z-P Global patterns of the effects of land-use changes on soil carbon stocks. Glob Ecol Conserv. 2016;5:127-38. https://doi.org/10.1016/j.gecco.2015. 12.004 .
118. Marques A, Martins IS, Kastner T, Plutzar C, Theurl MC, Eisenmenger $\mathrm{N}$, et al. Increasing impacts of land use on biodiversity and carbon sequestration driven by population and economic growth. Nat Ecol Evol. 2019;3(4):628-37. https://doi.org/10. 1038/s41559-019-0824-3.

119. van der Werf GR, Randerson JT, Giglio L, van Leeuwen TT, Chen Y, Rogers BM, et al. Global fire emissions estimates during 1997-2016. Earth Syst Sci Data. 2017;9(2):697-720. https://doi. org/10.5194/essd-9-697-2017.

120. Conchedda G, Tubiello FN. Drainage of organic soils and GHG emissions: validation with country data. Earth Syst Sci Data. 2020;12(4):3113-37. https://doi.org/10.5194/ essd-12-3113-2020.

121. Joosten $\mathrm{H}$. The Global Peatland CO2 Picture: peatland status and drainage related emissions in all countries of the world. 2010

122. Qiu C, Ciais P, Zhu D, Guenet B, Peng S, Petrescu AMR et al. Large historical carbon emissions from cultivated northern peatlands. Sci Adv. 2021; 7(23) https://doi.org/10.1126/sciadv.abf13 32

123. Houghton RA. Interactions between land-use change and climatecarbon cycle feedbacks. Curr Clim Change Rep. 2018;4(2):11527. https://doi.org/10.1007/s40641-018-0099-9.

124. Battye W, Aneja VP, Schlesinger WH. Is nitrogen the next carbon? Earth's Future. 2017;5(9):894-904. https://doi.org/10.1002/ 2017 ef000592.

125. Tubiello FN. Greenhouse gas emissions due to agriculture. In: Ferranti P, Berry EM, Anderson JR, editors. Encyclopedia of food security and sustainability. Oxford: Elsevier; 2019. p. 196-205.

126. Scheer C, Fuchs K, Pelster DE, Butterbach-Bahl K. Estimating global terrestrial denitrification from measured $\mathrm{N}_{2} \mathrm{O}:\left(\mathrm{N}_{2} \mathrm{O}+\right.$ $\mathrm{N}_{2}$ ) product ratios. Curr Opin Environ Sustain. 2020;47:72-80. https://doi.org/10.1016/j.cosust.2020.07.005.

127. Tian H, Yang J, Xu R, Lu C, Canadell JG, Davidson EA, et al. Global soil nitrous oxide emissions since the preindustrial era estimated by an ensemble of terrestrial biosphere models: magnitude, attribution, and uncertainty. Glob Chang Biol. 2019;25(2):640-59. https://doi.org/10.1111/gcb.14514.

128. Chang J, Peng S, Ciais P, Saunois M, Dangal SRS, Herrero M, et al. Revisiting enteric methane emissions from domestic ruminants and their delta(13) $\mathrm{CCH}_{4}$ source signature. Nat Commun. 2019;10(1):3420. https://doi.org/10.1038/s41467-019-11066-3.

129. Janssens-Maenhout G, Crippa M, Guizzardi D, Muntean M, Schaaf E, Dentener F, et al. EDGAR v4.3.2 Global Atlas of the three major greenhouse gas emissions for the period 19702012. Earth Syst Sci Data. 2019;11(3):959-1002. https://doi. org/10.5194/essd-11-959-2019.

130. Lal R, Smith P, Jungkunst HF, Mitsch WJ, Lehmann J, Nair PKR, et al. The carbon sequestration potential of terrestrial ecosystems. J Soil Water Conserv. 2018;73(6):145A-A152. https://doi.org/10.2489/jswc.73.6.145A.

131. Arneth A, Denton F, Agus F, Elbehri A, Erb K, Osman Elasha B et al. Framing and context. In: P.R. Shukla JS, E. Calvo Buendia, V. Masson-Delmotte, H.-O. Pörtner, D.C. Roberts, P. Zhai, R. Slade, S. Connors, R. van Diemen, M. Ferrat, E. Haughey, S. Luz, S. Neogi, M. Pathak, J. Petzold, J. Portugal Pereira, P. Vyas, E. Huntley, K. Kissick, M. Belkacemi, J. Malley, editor. Climate change and land: an IPCC special report on climate change, desertification, land degradation, sustainable land management, food security, and greenhouse gas fluxes in terrestrial ecosystems. 2019

132. Bastin JF, Finegold Y, Garcia C, Mollicone D, Rezende M, Routh $\mathrm{D}$, et al. The global tree restoration potential. Science. 2019;365(6448):76-9. https://doi.org/10.1126/science.aax08 48. 
133. Delzeit R, Pongratz J, Schneider JM, Schuenemann F, Mauser W, Zabel F. Forest restoration: expanding agriculture. Science. 2019;366(6463):316-7. https://doi.org/10.1126/science.aaz0705.

134. Zomer RJ, Trabucco A, Verchot LV, Muys B. Land area eligible for afforestation and reforestation within the clean development mechanism: a global analysis of the impact of forest definition. Mitig Adapt Strat Glob Change. 2007;13(3):219-39. https://doi. org/10.1007/s11027-007-9087-4.

135. Buendia EC, Guendehou S, Limmeechokchai B, Pipatti R, Rojas Y, Sturgiss R et al. 2019 Refinement to the 2006 IPCC Guidelines for National Greenhouse Gas Inventories. 2019

136. Skidmore AK, Wang T, de Bie K, Pilesjo P. Comment on "The global tree restoration potential". Science. 2019;366(6469) https://doi.org/10.1126/science.aaz0111

137. Sonntag S, Pongratz J, Reick CH, Schmidt H. Reforestation in a high- $\mathrm{CO}_{2}$ world-Higher mitigation potential than expected, lower adaptation potential than hoped for. Geophys Res Lett. 2016;43(12):6546-53. https://doi.org/10.1002/2016gl068824.

138. Seidl R, Thom D, Kautz M, Martin-Benito D, Peltoniemi M, Vacchiano G, et al. Forest disturbances under climate change. Nat Clim Chang. 2017;7:395-402. https://doi.org/10.1038/nclim ate3303.

139. McDowell NG, Allen CD, Anderson-Teixeira K, Aukema BH, Bond-Lamberty B, Chini L et al. Pervasive shifts in forest dynamics in a changing world. Science. 2020;368(6494) https:// doi.org/10.1126/science.aaz9463

140. Jones CD, Ciais P, Davis SJ, Friedlingstein P, Gasser T, Peters GP et al. Simulating the earth system response to negative emissions. Environ Res Lett. 2016;11(9) https://doi.org/10.1088/ 1748-9326/11/9/095012

141. Koch A, Brierley C, Lewis SL. Effects of Earth system feedbacks on the potential mitigation of large-scale tropical forest restoration. Biogeosciences. 2021;18(8):2627-47. https://doi.org/10. 5194/bg-18-2627-2021.

142. Luyssaert S, Schulze ED, Borner A, Knohl A, Hessenmoller D, Law BE, et al. Old-growth forests as global carbon sinks. Nature. 2008;455(7210):213-5. https://doi.org/10.1038/nature07276.

143. Luyssaert S, Schulze ED, Knohl A, Law BE, Ciais P, Grace J. Reply to: Old-growth forest carbon sinks overestimated. Nature. 2021;591(7851):E24-5. https://doi.org/10.1038/ s41586-021-03267-y.

144. Jiang M, Medlyn BE, Drake JE, Duursma RA, Anderson IC, Barton CVM, et al. The fate of carbon in a mature forest under carbon dioxide enrichment. Nature. 2020;580(7802):227-31. https://doi.org/10.1038/s41586-020-2128-9.

145. Kreidenweis U, Humpenöder F, Stevanović M, Bodirsky BL, Kriegler E, Lotze-Campen $\mathrm{H}$ et al. Afforestation to mitigate climate change: impacts on food prices under consideration of albedo effects. Environ Res Lett. 2016;11(8) https://doi.org/10. 1088/1748-9326/11/8/085001

146. Windisch MG, Davin EL, Seneviratne SI. Prioritizing forestation based on biogeochemical and local biogeophysical impacts. Nat Clim Chang. 2021;11(10):867-71. https://doi. org/10.1038/s41558-021-01161-z.

147. Roe S, Streck C, Obersteiner M, Frank S, Griscom B, Drouet $\mathrm{L}$, et al. Contribution of the land sector to a $1.5^{\circ} \mathrm{C}$ world. Nature Clim Change. 2019;9(11):817-28. https://doi.org/10. 1038/s41558-019-0591-9.

148. de Noblet-Ducoudré N, Boisier J-P, Pitman A, Bonan GB, Brovkin V, Cruz F, et al. Determining robust impacts of landuse-induced land cover changes on surface climate over North America and Eurasia: results from the first set of LUCID experiments. J Clim. 2012;25(9):3261-81. https://doi.org/10. 1175/jcli-d-11-00338.1.

149. Winckler J, Lejeune Q, Reick CH, Pongratz J. Nonlocal effects dominate the global mean surface temperature response to the biogeophysical effects of deforestation. Geophys Res Lett. 2019;46(2):745-55. https://doi.org/10.1029/2018gl080211.

150. Winckler J, Reick CH, Luyssaert S, Cescatti A, Stoy PC, Lejeune Q, et al. Different response of surface temperature and air temperature to deforestation in climate models. Earth Syst Dyn. 2019;10(3):473-84. https://doi.org/10.5194/ esd-10-473-2019.

151. Boysen LR, Brovkin V, Pongratz J, Lawrence DM, Lawrence P, Vuichard N, et al. Global climate response to idealized deforestation in CMIP6 models. Biogeosciences. 2020;17(22):561538. https://doi.org/10.5194/bg-17-5615-2020.

152. Lejeune Q, Davin EL, Gudmundsson L, Winckler J, Seneviratne SI. Historical deforestation locally increased the intensity of hot days in northern mid-latitudes. Nat Clim Chang. 2018;8(5):386-90. https://doi.org/10.1038/s41558-018-0131-z.

153. Davin EL, Rechid D, Breil M, Cardoso RM, Coppola E, Hoffmann P, et al. Biogeophysical impacts of forestation in Europe: first results from the LUCAS (Land Use and Climate Across Scales) regional climate model intercomparison. Earth Syst Dyn. 2020;11(1):183-200. https://doi.org/10.5194/ esd-11-183-2020.

154. Duveiller G, Forzieri G, Robertson E, Li W, Georgievski $\mathrm{G}$, Lawrence $\mathrm{P}$, et al. Biophysics and vegetation cover change: a process-based evaluation framework for confronting land surface models with satellite observations. Earth Syst Sci Data. 2018;10(3):1265-79. https://doi.org/10.5194/ essd-10-1265-2018.

155. Betts RA. Offset of the potential carbon sink from boreal forestation by decreases in surface albedo. Nature. 2000;408(6809):18790. https://doi.org/10.1038/35041545.

156. Pongratz J, Reick CH, Raddatz T, Caldeira K, Claussen M. Past land use decisions have increased mitigation potential of reforestation. Geophys Res Lett. 2011;38(15) https://doi.org/10.1029/ $2011 \mathrm{gl} 047848$

157. Meier R, Schwaab J, Seneviratne SI, Sprenger M, Lewis E, Davin EL. Empirical estimate of forestation-induced precipitation changes in Europe. Nat Geosci. 2021;14(7):473-8. https:// doi.org/10.1038/s41561-021-00773-6.

158. Khanna J, Medvigy D, Fueglistaler S, Walko R. Regional dryseason climate changes due to three decades of Amazonian deforestation. Nat Clim Chang. 2017;7(3):200-4. https://doi.org/10. 1038/nclimate 3226

159. Spracklen DV, Garcia-Carreras L. The impact of Amazonian deforestation on Amazon basin rainfall. Geophys Res Lett. 2015;42(21):9546-52. https://doi.org/10.1002/2015gl066063.

160. Lovejoy TE, Nobre C. Amazon tipping point: Last chance for action. Sci Adv. 2019;5(12):eaba2949. https://doi.org/10.1126/ sciadv.aba2949.

161. Douville H, K. Raghavan, J. Renwick, R. P. Allan, P. A. Arias, M. Barlow, R. Cerezo-Mota, A. Cherchi, T. Y. Gan, J. Gergis, D. Jiang, A. Khan, W. Pokam Mba, D. Rosenfeld, J. Tierney, O. Zolina. Water Cycle Changes. In: Masson-Delmotte V, P. Zhai, A. Pirani, S. L. Connors, C. Péan, S. Berger, N. Caud, Y. Chen, L. Goldfarb, M. I. Gomis, M. Huang, K. Leitzell, E. Lonnoy, J. B. R. Matthews, T. K. Maycock, T. Waterfield, O. Yelekçi, R. Yu and B. Zhou, editor. Climate change 2021: The Physical Science Basis. Contribution of Working Group I to the Sixth Assessment Report of the Intergovernmental Panel on Climate Change: Cambridge University Press. In Press; 2021.

162. Devaraju N, Bala G, Modak A. Effects of large-scale deforestation on precipitation in the monsoon regions: remote versus local effects. Proc Natl Acad Sci U S A. 2015;112(11):3257-62. https://doi.org/10.1073/pnas.1423439112.

163. Erb KH, Luyssaert S, Meyfroidt P, Pongratz J, Don A, Kloster $S$, et al. Land management: data availability and process 
understanding for global change studies. Glob Chang Biol. 2017;23(2):512-33. https://doi.org/10.1111/gcb.13443.

164. Thiery W, Davin EL, Lawrence DM, Hirsch AL, Hauser M, Seneviratne SI. Present-day irrigation mitigates heat extremes. J Geophys Res Atmos. 2017;122(3):1403-22. https://doi.org/10. 1002/2016jd025740.

165. Thiery W, Visser AJ, Fischer EM, Hauser M, Hirsch AL, Lawrence DM, et al. Warming of hot extremes alleviated by expanding irrigation. Nat Commun. 2020;11(1):290. https://doi.org/10. 1038/s41467-019-14075-4.

166. de Vrese P, Stacke T. Irrigation and hydrometeorological extremes. Clim Dyn. 2020;55(5-6):1521-37. https://doi.org/10. 1007/s00382-020-05337-9.

167. de Vrese P, Hagemann S, Claussen M. Asian irrigation, African rain: remote impacts of irrigation. Geophys Res Lett. 2016;43(8):3737-45. https://doi.org/10.1002/2016gl068146.

168. Schwaab J, Davin EL, Bebi P, Duguay-Tetzlaff A, Waser LT, Haeni M, et al. Increasing the broad-leaved tree fraction in European forests mitigates hot temperature extremes. Sci Rep. 2020;10(1):14153. https://doi.org/10.1038/s41598-020-71055-1.

169. Naudts K, Chen Y, McGrath MJ, Ryder J, Valade A, Otto J, et al. Europe's forest management did not mitigate climate warming. Science. 2016;351(6273):597-600. https://doi.org/10.1126/scien ce.aad7270.

170. Pitman AJ, Avila FB, Abramowitz G, Wang YP, Phipps SJ, de Noblet-Ducoudré N. Importance of background climate in determining impact of land-cover change on regional climate. Nat Clim Chang. 2011;1(9):472-5. https://doi.org/10.1038/nclim ate1294.

171. Winckler J, Reick CH, Pongratz J. Why does the locally induced temperature response to land cover change differ across scenarios? Geophys Res Lett. 2017;44(8):3833-40. https://doi.org/10. 1002/2017g1072519.

172. Li Y, De Noblet-Ducoudré N, Davin EL, Motesharrei S, Zeng N, Li S, et al. The role of spatial scale and background climate in the latitudinal temperature response to deforestation. Earth Syst Dyn. 2016;7(1):167-81. https://doi.org/10.5194/esd-7-167-2016.

173. Chen C, Park T, Wang X, Piao S, Xu B, Chaturvedi RK, et al. China and India lead in greening of the world through land-use management. Nat Sustain. 2019;2:122-9. https://doi.org/10. 1038/s41893-019-0220-7.

174. Lu F, Hu H, Sun W, Zhu J, Liu G, Zhou W, et al. Effects of national ecological restoration projects on carbon sequestration in China from 2001 to 2010. Proc Natl Acad Sci U S A. 2018;115(16):4039-44. https://doi.org/10.1073/pnas.17002 94115.

175. Piao S, Wang X, Wang K, Li X, Bastos A, Canadell JG, et al. Interannual variation of terrestrial carbon cycle: issues and perspectives. Glob Chang Biol. 2020;26(1):300-18. https://doi.org/ 10.1111/gcb.14884.

176. Hirsch AL, Guillod BP, Seneviratne SI, Beyerle U, Boysen LR, Brovkin V, et al. Biogeophysical impacts of land-use change on climate extremes in low-emission scenarios: results from HAPPILand. Earth's Future. 2018;6(3):396-409. https://doi.org/10. 1002/2017EF000744.

177. Hantson S, Knorr W, Schurgers G, Pugh TAM, Arneth A. Global isoprene and monoterpene emissions under changing climate, vegetation, $\mathrm{CO}_{2}$ and land use. Atmos Environ. 2017;155:35-45. https://doi.org/10.1016/j.atmosenv.2017.02.010.

178. Andrews T, Betts RA, Booth BBB, Jones CD, Jones GS. Effective radiative forcing from historical land use change. Clim Dyn. 2016;48(11-12):3489-505. https://doi.org/10.1007/ s00382-016-3280-7.

179. Heald CL, Spracklen DV. Land use change impacts on air quality and climate. Chem Rev. 2015;115(10):4476-96. https://doi.org/ $10.1021 / \mathrm{cr} 500446 \mathrm{~g}$.
180. Claussen M, Brovkin V, Ganopolski A. Biogeophysical versus biogeochemical feedbacks of large-scale land cover change. Geophys Res Lett. 2001;28(6):1011-4. https://doi.org/10.1029/2000g 1012471.

181. Quesada B, Arneth A, de Noblet-Ducoudré N. Atmospheric, radiative, and hydrologic effects of future land use and land cover changes: a global and multimodel climate picture. J Geophys Res Atmo. 2017;122(10):5113-31. https://doi.org/10.1002/2016j d025448.

182. Lee X, Goulden ML, Hollinger DY, Barr A, Black TA, Bohrer G, et al. Observed increase in local cooling effect of deforestation at higher latitudes. Nature. 2011;479(7373):384-7. https://doi.org/ 10.1038/nature 10588 .

183. Frank S, Havlík P, Stehfest E, van Meijl H, Witzke P, PérezDomínguez I, et al. Agricultural non-CO2 emission reduction potential in the context of the $1.5^{\circ} \mathrm{C}$ target. Nat Clim Change. 2018;9(1):66-72. https://doi.org/10.1038/s41558-018-0358-8.

184. Clark MA, Domingo NGG, Colgan K, Thakrar SK, Tilman D, Lynch J, et al. Global food system emissions could preclude achieving the 1.5 degrees and 2 degrees $C$ climate change targets. Science. 2020;370(6517):705-8. https://doi.org/10.1126/science. aba7357.

185. Seneviratne SI, Phipps SJ, Pitman AJ, Hirsch AL, Davin EL, Donat MG, et al. Land radiative management as contributor to regional-scale climate adaptation and mitigation. Nat Geosci. 2018;11(2):88-96. https://doi.org/10.1038/s41561-017-0057-5.

186. Pitman AJ, Lorenz R. Scale dependence of the simulated impact of Amazonian deforestation on regional climate. Environ Res Lett. 2016;11(9) https://doi.org/10.1088/1748-9326/11/9/094025

187. Cohn AS, Bhattarai N, Campolo J, Crompton O, Dralle D, Duncan J, et al. Forest loss in Brazil increases maximum temperatures within $50 \mathrm{~km}$. Environ Res Lett. 2019;14(8):084047. https://doi.org/10.1088/1748-9326/ab31fb.

188. Roy SB. Mesoscale vegetation-atmosphere feedbacks in Amazonia. J Geophys Res. 2009;114(D20) https://doi.org/10.1029/ 2009jd012001

189. Bauer P, Stevens B, Hazeleger W. A digital twin of Earth for the green transition. Nat Clim Chang. 2021;11(2):80-3. https://doi. org/10.1038/s41558-021-00986-y.

190. van Vuuren DP, Batlle Bayer L, Chuwah C, Ganzeveld L, Hazeleger W, van den Hurk B et al. A comprehensive view on climate change: coupling of earth system and integrated assessment models. Environ Res Lett. 2012;7(2) https://doi.org/10.1088/ 1748-9326/7/2/024012

191. Thornton PE, Calvin K, Jones AD, Di Vittorio AV, Bond-Lamberty B, Chini L, et al. Biospheric feedback effects in a synchronously coupled model of human and Earth systems. Nat Clim Chang. 2017;7(7):496-500. https://doi.org/10.1038/nclimate33 10.

192. Alexander P, Rabin S, Anthoni P, Henry R, Pugh TAM, Rounsevell MDA, et al. Adaptation of global land use and management intensity to changes in climate and atmospheric carbon dioxide. Glob Chang Biol. 2018;24(7):2791-809. https://doi.org/10.1111/ gcb. 14110 .

193. Müller-Hansen F, Schlüter M, Mäs M, Donges JF, Kolb JJ, Thonicke K, et al. Towards representing human behavior and decision making in Earth system models - an overview of techniques and approaches. Earth Syst Dyn. 2017;8(4):977-1007. https://doi.org/10.5194/esd-8-977-2017.

Publisher's Note Springer Nature remains neutral with regard to jurisdictional claims in published maps and institutional affiliations. 